\title{
What do Firms Gain from Patenting? The Case of the Global ICT Industry.
}

\author{
Dimitrios Exadaktylos * $^{*}$ Mahdi Ghodsi ${ }^{\dagger} \quad$ Armando Rungi ${ }^{\ddagger}$
}

This version: January 2023

\begin{abstract}
This study investigates the causal relationship between patent grants and firms' dynamics in the Information and Communication Technology (ICT) industry, as the latter is a peculiar sector of modern economies, often under the lens of antitrust authorities. For our purpose, we exploit matched information about financial accounts and patenting activity in 2009-2017 by 179,660 companies operating in 39 countries. Preliminarily, we show how bigger companies are less than $2 \%$ of the sample, although they concentrate about $89 \%$ of the grants obtained in the period of analyses. Thus, we test that patent grants in the ICT industry have a significant and large impact on market shares and firm size of smaller companies (31.5\% and $30.7 \%$, respectively) in the first year after the grants, while we have no evidence of an impact for bigger companies. After a novel instrumental variable strategy that exploits information at the level of patent offices, we confirm that most of the effects on smaller companies are due to the protection of property rights and not to the innovative content of inventions. Finally, we never observe a significant impact on either profitability or productivity for any firm size category. Eventually, we discuss how our findings support the idea that the ICT industry is a case of endogenous $R \& D$ sunk costs, which prevent profit margins from rising in the presence of a relatively high market concentration.
\end{abstract}

JEL Classification: O31, O34, L22, L25, F23

Keywords: intellectual property rights, ICT, market competition, endogenous sunk costs, firm level

\footnotetext{
*d.exadaktylos@imtlucca.it. Laboratory for the Analysis of Complex Economic Systems, piazza San Francesco 19 - 55100 Lucca

†ghodsi@wiiw.ac.at. Vienna University of Economics and Business (WU); the Vienna Institute for International Economic Studies (wiiw) www.wiiw.ac.at, Rahlgasse 3, 1060 Vienna, Austria.

‡armando.rungi@imtlucca.it. Corresponding author. Laboratory for the Analysis of Complex Economic Systems, piazza San Francesco 19 - 55100 Lucca

$\S$ Acknowledgement: Authors acknowledge funding by the Anniversary Fund of the Oesterreichische Nationalbank (Project No. 18128). Support provided by Oesterreichische Nationalbank for this research is gratefully acknowledged.
} 


\section{Introduction}

Over the past decades, digitalization has played a significant role in the transformation of many production processes. Companies operating in the Information and Communication Technologies (ICT) industry have become major players globally, while the so-called digital sector has rapidly grown. The industry contributes innovative goods and services destined for consumers, and technological inputs are destined for firms across many other sectors. The benefits of investing in ICT are evident because many firms can potentially gain in terms of efficiency (Brynjolfsson and Hitt, 2003) through a

reshaping of innovation strategies (Nambisan et al., 2019). Thus, policymakers tend to attribute a high value to the ICT global industry as an engine of economic growth. However, concerns about a fast market concentration among a few Big-Tech global players have been raised. Thus, antitrust authorities in the US and the European Union started their probes to check for abuses. Regarding mechanisms on how market concentration is built and preserved, the regime of Intellectual Property Rights (IPR) is among the prime suspects, as critics assume that companies obtain unfair market advantages from excessive protection granted through patents.

Against the previous background, we aim to empirically investigate the relationship between patenting activity and firm-level dynamics in the global ICT sector in 20092017. For our purpose, we exploit a sample of 179,660 firms active in 39 countries with matched information on financial accounts and patent grants. First, we provide a few insights into the heterogeneous patenting activity by ICT firms over time and across geography. Notably, we find that IPRs are highly concentrated in a few portfolios since less than $2 \%$ of firms are responsible for about $89 \%$ of patent grants. Moreover, most active patentees are located in the United States and Asia, while EU firms lag behind in patenting activity. When we drill down into the details, we find that very large firms in the US with more than 1,000 employees register up to 45 new patents on average in our period of analyses. Therefore, when we look at financial accounts, we find that the number of patent grants positively correlates with market shares, productivity, firm size and capital intensity.

Motivated by preliminary evidence, we challenge correlations by employing a composite empirical strategy. Our main interest is: i) to understand how patent grants in the ICT industry have an impact on firms' dynamics while controlling for reverse causality; ii) to separate the impact of protection of property rights per se on firms' 
dynamics from the effect induced on firms' outcomes by the innovative contents of the registered inventions.

As for reverse causality, we apply a diff-in-diff strategy for panel data settings recently proposed by Callaway and Sant'Anna (2021), which is useful to us because we have multiple treatment periods, variation in treatment timing, and we need to make sure that the assumption of parallel trends is made conditional on observables. Thus, having complete information on the timing of patents' registration processes, we consider a firm treated if it has been granted property rights in our period of analyses. At this stage, we find that the impact of patent grants is high and significant only in the case of smaller firms, i.e., after we consider firms that have a number of employees that is below the median value. In this case, we find an average high impact on market shares $(31.5 \%)$ due to higher sales $(30.7 \%)$ in the first year after the patent grant. Notably, bigger firms are not significantly affected by patent grants in any of the specifications we tried.

Quite surprisingly, neither profits nor productivity seem to be affected by patent grants after controlling for reverse causality. Thus, we discuss the peculiarities of the ICT industry that arguably represents a poster child of a sector with endogenous sunk $\operatorname{costs}^{1}$. Following the seminal works by Sutton (1998), we argue that ICT global players have the incentive to invest in $\mathrm{R} \& \mathrm{D}$ to increase market shares since consumers evaluate product differentiation by looking at innovative features available on the market. Yet, given high investments in R\&D, successful patent grants do not allow assignees an immediate increase in capital returns per se. On the contrary, most active patentees in the ICT global industry seem to show relatively more short-term financial distress in our data than smaller ones, possibly due to a rush in innovation.

In the second stage of our analyses, we are interested in disentangling the impact of protection or property rights. We assume that previous diff-in-diff results confound the roles of intellectual property rights protection and the innovation content of the inventions protected by the patents. Companies could have increased market shares simply by selling more innovative products and not necessarily because they obtained the protection of intellectual property rights. From another perspective, we argue that

\footnotetext{
${ }^{1}$ For a useful review on the different approaches to investigate market power in modern economies with an industrial theoretical perspective, see Berry et al. (2019).
} 
the ability to ask for a patent and obtain a grant from a patent office is also correlated with the ability to generate innovative products, and thus, pairwise correlations with market shares and firm size may be spurious. Therefore, to distil the impact of IPR protection, we propose a novel instrumental variable strategy based on information collected at the level of patent offices. Our strategy exploits the exogenous experience of non-ICT firms in getting grants in the same ICT technology-office-year cells as ICT firms. In fact, we find that it is quite common for companies to obtain patents in technologies that are not strictly related to their core activities. In our case, it is possible for a non-ICT firm to ask for a patent for a technology related to the ICT industry, thus undergoing the same evaluation process by experts at the patent offices. Our intuition is that companies in other sectors do not compete with those in the ICT industry, hence our exclusion restriction assumption. Yet, regardless of a company's affiliation industry, experts shall evaluate with the same criteria whether the inventions are innovative and thus worthy of protection. That's why we expect the propensity of ICT firms to obtain a grant in a specific technology in a given year to be correlated with the number of grants and/or the share of grants out of total applications in the same technology and the same year (relevance assumption). Eventually, both tests for the exclusion restrictions and the relevance assumptions confirm the validity of the chosen instruments.

Therefore, we implement our IV strategy considering as treated those firms that obtain unique patents in our period of analysis, i.e., firms that obtain protection for unique innovations at the moment we can observe them. These companies are relatively smaller compared to bigger players in the global ICT industry. We find that the positive impact on a firm's market share and size is still there. Notably, an increase in market share after a patent grant is relatively high (29.7\%) and statistically significant only in the first year after the grant. Latter results are in line and similar in magnitudes to those obtained in simpler diff-in-diff specifications in the case of small and medium enterprises. Thus, we conclude that most of the impact of patent grants on smaller businesses can be ceteris paribus attributed to property rights protection. Once again, we do not observe any significant pattern in profitability or productivity, in line with our conjecture that the global ICT industry is a case of high sunk costs in R\&D.

Importantly, we make our findings robust to different corporate control strategies since we are aware that ICT headquarters can delegate subsidiaries to hold intellectual property rights. It is the case when $\mathrm{R} \& \mathrm{D}$ labs are located within corporate boundaries, 
for example, in the case of multinational enterprises that use their subsidiaries across national borders to invest in innovation and to hold patent portfolios.

To grasp the relevance of patenting activity in the ICT global industry, we report in Table 1 a match of the top ICT global firms according to Fortune Global 500 in the reference year 2020 with the stock of patents they have accumulated over time, as from our matched data set ${ }^{2}$. The Fortune's ranking is originally based on global revenues, and consistently, we match in the last column with information on all the patents that could have been obtained historically by either a parent company in the origin country or its subsidiaries located wherever in the rest of the world.

Table 1: Top ICT global firms and stocks of patents

\begin{tabular}{|c|c|c|c|c|c|}
\hline $\begin{array}{c}\text { Fortune's } 500 \\
\text { Global rank }\end{array}$ & Company & Country & $\begin{array}{l}\text { Revenues } \\
\text { (bln USD) }\end{array}$ & N. employees & $\begin{array}{l}\text { N. granted } \\
\text { patents }\end{array}$ \\
\hline 1 & Apple & United States & 260,174 & 137,000 & 54,536 \\
\hline 2 & Samsung Electronics & South Korea & 197,705 & 287,439 & 641,743 \\
\hline 3 & Foxconn & Taiwan & 178,860 & 757,404 & 2,266 \\
\hline 4 & Alphabet & United States & 161,857 & 118,899 & 60,049 \\
\hline 5 & Microsoft & United States & 125,843 & 144,000 & 89,635 \\
\hline 6 & Huawei & China & 124,316 & 194,000 & 98,880 \\
\hline 7 & Dell Technologies & United States & 92,154 & 165,000 & 11,509 \\
\hline 8 & Hitachi & Japan & 80,639 & 301,056 & 268,598 \\
\hline 9 & IBM & United States & 77,147 & 383,056 & 216,837 \\
\hline 10 & Sony & Japan & 75,972 & 111,700 & 219,092 \\
\hline 11 & Intel & United States & 71,965 & 110,800 & 91,214 \\
\hline 12 & Facebook & United States & 70,697 & 44,942 & 12,381 \\
\hline 13 & Panasonic & Japan & 68,897 & 259,835 & 384,817 \\
\hline 14 & HP Inc. & United States & 58,756 & 44,942 & 61,715 \\
\hline 15 & Tencent & China & 54,613 & 62,885 & 18,552 \\
\hline 16 & LG Electronics & South Korea & 53,464 & 74,000 & 315,038 \\
\hline 17 & Cisco & United States & 51,904 & 75,900 & 17,997 \\
\hline 18 & Lenovo & China & 50,716 & 63,000 & 27,716 \\
\hline
\end{tabular}

Note: The table indicates the list of top ICT global firms in the year 2020 according to the Fortune Global 500 ranking and the total number of patents that have been granted at any time in their business history in the same year, as reported by the Orbis Intellectual Property database.

\footnotetext{
${ }^{2}$ Please note that in following analyses we will always focus on flows of grants by year, while Table 1 reports stocks of grants accumulated up to 2020, i.e., including grants that have been obtained since the incorporation.
} 
Notably, we record an average stock of about 160 thousand by top ICT firms; the most historically active assignee has been Samsung Electronics in South Korea, with up to 641,743 grants. The younger Foxconn in Taiwan is the one relying relatively less on patenting activity with an albeit non-negligible stock of 2,266 patents. In the following analysis, we will go beyond bigger corporations to investigate the role of medium and smaller companies while showing how patenting activity can be heterogeneous within the global industry in a relationship with firm-level outcomes.

The rest of the paper is organized as follows. Section 2 relates our work to previous literature. Section 3 introduces data and provides preliminary evidence extracted from our matched patent-firm sample. In section 4, we discuss our identification strategy and comment results. Section 5 introduces some robustness and sensitivity checks. Finally, Section 6 concludes with final remarks.

\section{Related literature}

First of all, We relate our contribution to the vast strand of literature that investigates the impact of IPR protection. The latter is usually justified as a way to introduce artificial scarcity and amend non-rivalry and non-excludability in the consumption of knowledge. The economic rationale of IPR protection is that early positive externalities reduce the incentives for knowledge producers who may underinvest in an industry that significantly contributes to social welfare and economic growth. In this context, patents are supposed to be a way to counterbalance market imperfections while generating a temporary legally enforced monopoly to guarantee producers profits from knowledge generation.

Over the last years, however, several scholars have raised concerns about the perverse mechanisms that IPR practices can bring. In their seminal works, Dosi et al. (2006) and Boldrin and Levine (2008) build cases against intellectual monopolies discussing evidence that IPR regimes have, at best, no impact or, in some cases, a negative impact on innovation rates. IPRs may favour rent-seeking behaviour by firms that benefit from the monopolistic power granted on the knowledge they generate, therefore reducing the diffusion of innovation and reducing social welfare. Interestingly for our case, Boldrin and Levine (2013) point out how there seems to be no positive relationship between patenting activity and productivity. Expressly, the authors point to an inconsistency 
between the partial equilibrium, where patents may still be able to raise incentives for incumbent producers, and the general equilibrium, where protection can reduce aggregate innovation rates.

Looking into specific domains, Henry and Stiglitz (2010) discuss the case of solutions for slowing down climate change and enhancing environmental protection, where patenting is most problematic. In particular, they sketch the case study of research in genetically modified organisms, where a different regime has brought more comprehensive social benefits. Interestingly, Moser (2013) and van Gompel (2019) review other cases in economic history when, in the absence of modern IPR regimes, different forms of protection or even knowledge sharing were also able to accompany waves of essential innovations. Eventually, Cimoli et al. (2014) discuss how modern IPR regimes could represent an obstacle to knowledge diffusion in developing countries, which may need to imitate prosperous developed countries to boost economic growth. Yet, on the other front of the controversy, other scholars stress that IPR protection should be even more critical in modern times if one considers the strategic role that intangible assets play for the economic potential of regions and countries (Ziedonis, 2008; Haskel and Westlake, 2018).

Nonetheless, the research strand based on the seminal works by Sutton (1986, 1991, 1998) supports the idea that there are industries that operate with endogenous sunk costs, where there is a structural lower bound in market shares. Briefly, some industries have to invest a relatively higher share in $\mathrm{R} \& \mathrm{D}$, advertising and other activities to enhance consumers' willingness to pay for the products they offer, independent of how big the demand already is. See also previous ideas in Shaked and Sutton $(1983,1987)$. In this case, a market equilibrium implies a relatively higher market share that is associated with higher technological barriers to market entry and, thus, a smaller pool of firms that can profitably operate in the industry.

For a competing framework, we refer to Acs and Audretsch (1988) and Geroski and Pomroy (1990), who underline how innovation may be negatively associated with market concentration. Aghion et al. (2005) suggest that firms have a market advantage when they innovate in industries that suffer from lower competition. Otherwise, when competition is higher, market followers have lower incentives to innovate than the leaders. On the same line, Blundell et al. (1999) also challenge the association between market share and innovation. After exploiting dynamic count data models, they find a robust and positive effect of market shares on patent stocks, although increased product market competition in the industry tends to stimulate innovative activity. 
Against the previous background, our primary concern is to investigate the case of the ICT industry as a typical example of an innovative segment of modern economic activities, which contributes to economic growth thanks to the widespread adoption of technologies that enhance the productivity of both private and public activities ${ }^{3}$. Firms in ICT have unique business models and require technological platforms that engage many downstream producers (Teece, 2018). Given the relevance of innovations coming from the ICT industry, producers seem particularly keen on claiming IPR protection through court proceedings (Graham and Vishnubhakat, 2013), thus keeping their market advantages.

In this contribution, we do find support for the existence of endogenous sunk costs in the market structure of the ICT industry, in line with the hypothesis by Sutton (1998), because higher market shares do come as a result of patent grants and, yet, we do not find causal evidence of higher profit margins. Efforts by ICT companies to reach consumers with the most innovative products are not rewarded per se with increasing profits, although such innovative activities are necessary to outlive the ICT market.

Beyond the ICT industry, we believe our results can relate to previous evidence on firms' outcomes from US industries published by Balasubramanian and Sivadasan (2011), according to which increases in patent stocks associate with increases in firm size, scope, skill intensity, and capital intensity. Please note, however, how Balasubramanian and Sivadasan (2011) do not test any impact on market shares, thus leaving the reader agnostic about the consequences of IPR on market structures.

Eventually, we relate our study to recent efforts devoted to studying the endogenous decision of patenting. For our instrumental variable strategy, we take inspiration from the work by Farre-Mensa et al. (2020), who provide evidence on the value of patents to startups. As in that case, we leverage on information coming from country patent offices, given the propensity to grant patents out of total applications. In our case, the exogenous variation comes from applicant firms that operate in industries different from the ICT industry, although they could apply for grants in the same ICT technology in the same year. For an alternative identification strategy adopting information at the

\footnotetext{
${ }^{3}$ Please note, however, the existence of a strand of research that questions the actual contribution of modern ICTs to aggregate productivity as unsatisfactory if measured against initial expectations. The argument follows that one should expect much more productivity from adopting new technologies than what is measured, hence a so-called productivity paradox. Among others, see Acemoglu et al. (2014).
} 
patent offices, see also the work by Kline et al. (2019), whose aim is to identify patents that are ex-ante valuable using the information on both accepted and rejected patent applications.

More controversial is the relationship between patenting and productivity, which is not robust to reverse causality in our study. In the US, Balasubramanian and Sivadasan (2011) find only a weak significance of the nexus after using data similar to ours matched at the firm-patent level. Unfortunately, we can only loosely relate to previous studies because we cannot retrieve similar indicators of R\&D expenses (Griffith et al., 2006; Mairesse and Robin, 2009; Mohnen and Hall, 2013; Crespi and Zuniga, 2012). It remains true that productivity correlates with a higher number of patents, but these correlations fade away after we control for the direction of causality. Eventually, we could recall the work by Bloom and Van Reenen (2002), who find that patents could have a significant impact on firm-level productivity only in the longer run, once inventions are incorporated into the production processes and efforts have been made to promote new products or production processes. Yet, from our viewpoint, the empirical evidence provided by Bloom and Van Reenen (2002) is not entirely convincing. We argue that the authors test their hypotheses on a highly self-selected sample of only about 200 firms that can stay quoted at the stock exchange throughout the entire period of analyses, thus not representative of the underlying business population that would include smaller and medium-sized firms.

In conclusion, please note that we always make our analyses robust to different definitions of the corporate perimeter, thus encompassing patents that are either granted to parent companies or their subsidiaries. In this way, we can control for optimal strategies by multinational enterprises that can, for example, locate part of their R\&D activities in countries where IPR regimes are more favourable or where taxation is relatively lower Skeie et al. (2017) on R\&D activities. It is the case of IPR regimes where patent boxes are allowed; thus, revenues from granted patents are exempted from taxes to benefit from higher profits from international activities (Bösenberg and Egger, 2017; Alstadsæter et al., 2018; Davies et al., 2020). In general, there is ample evidence that domestic and multinational enterprises in any sector can also take advantage of technology developed across different geographic regions, thus exploiting local subsidiaries for reverse knowledge transfer (Driffield et al., 2016). Therefore, an exclusive focus on parent companies would neglect an essential share of companies' innovation efforts. 


\section{$3 \quad$ Data and preliminary evidence}

\subsection{Data on firms and patents}

For our purpose, we exploit a matched data set of firms and registered patents in the period 2009-2017 sourced from the ORBIS database ${ }^{4}$, compiled by the Bureau Van Dijk. In particular, the module on Intellectual Property links companies and other entities (i.e., assignees of IPR) to their original patent filings collected from PATSTAT, the global database maintained by the European Patent Office. Usefully for our scope, the IP module by Orbis follows: i) the evolution of each patent filing, from the publication to the moment the property right is granted; ii) the changes in property rights from one assignee to another, e.g., in case of companies' mergers and acquisitions. Previous users of the same database include Noailly and Smeets (2015), who study the effect of technological change on environmental performance, and Alstadsæter et al. (2018), who investigate the determinants of patent registration. Andrews et al. (2014) also use a similar matched patent-firm data set to identify the impact of first patenting on firm performance across industries and countries.

Having different countries on a timeline, we apply exchange rates and deflate firms' financial accounts to express nominal values in constant 2015 US dollars. Exchange rates from national currencies are originally provided by the Bureau Van Dijk. At the same time, deflators are primarily sourced from either the OECD STAN Database or Eurostat for gross output, intermediate, and capital goods by country and sector of activity, respectively. In cases where deflators are unavailable at the two-digit or a more aggregate sector level, we use the GDP deflators at the country level. Deflators for Taiwan do not appear in the OECD or Eurostat, and we source them from the official local statistics office.

Although the IP module by Orbis includes patents and assignees from all over the world, we can keep only patents held by firms for which we have the basic financial information that we need for testing our hypotheses Eventually, we end up with a sample of 179, 660 firms active in 39 countries and operating in the ICT industry.

\footnotetext{
${ }^{4}$ The ORBIS database has become a standard source for global financial accounts. See for example Gopinath et al. (2017), Cravino and Levchenko (2016), Del Prete and Rungi (2017), and Fattorini et al. (2020). The coverage of smaller firms and details about financial accounts may vary among countries depending on the requirements of national business registries, as observed in Kalemli-Ozcan et al. (2015).
} 
Eventually, we have to define an ICT perimeter encompassing both firms and patents, as both come with different classification systems that do not always match. It is quite possible that ICT firms obtain patents in non-ICT technologies, as it is the case that non-ICT firms obtain grants in ICT technologies. Actually, the latter is a case that we want to exploit for the potential of an identification strategy in the following paragraphs. In the case of firms, we will consider ICT firms those that belong to either manufacturing or services industries following the work made by Benages et al. (2018), who compiled the 2018 PREDICT database for the European Commission. In Appendix Tables A2 and A1, we enlist countries and NACE 2-digit industries, respectively, included in our sample. In the case of patents and related applications to patent offices, we will consider ICT technologies based on a classification proposed by Eurostat and based on 4-digit subclasses of the International Patent Classification (IPC) system $^{5}$.

\subsection{Preliminary evidence}

First, we provide a snapshot of the heterogeneous distributions of patents by ICT firms, and we compare it with firm size distribution. Figure 1 shows the density of firms in four main size categories by the number of employees in the last year of sample coverage: 1-20; 21-250; 251-1000; higher than 1,000. As expected, the largest category is the one with smaller firms $(74.1 \%)$, whereas bigger corporations with more than 1,000 employees represent only $1.7 \%$ of the sample. This is in line with most evidence about the heterogeneous distribution of firm size within any industry, not specifically of the ICT industry.

What is peculiar is the evidence reported in Figure 2, which shows that the category of very large firms, on the right of the distribution, actually accounts for $89.4 \%$ of the patents that have been granted in our period of analyses. The latest is striking evidence that IPRs are highly concentrated in the ICT industry among a handful of players that can get a high number of grants, albeit in a short period of time, while most of the smaller firms are active in the ICT industry, although they operate without getting any new grants in our period of analyses. We believe that such a concentration of IPRs among a few companies is preliminary evidence that is interesting per se, as it has not been exposed elsewhere.

\footnotetext{
${ }^{5}$ For further details, please see the original document available at https://ec.europa.eu/ eurostat/cache/metadata/Annexes/pat_esms_an2.pdf
} 
Figure 1: Firm size in the ICT sector

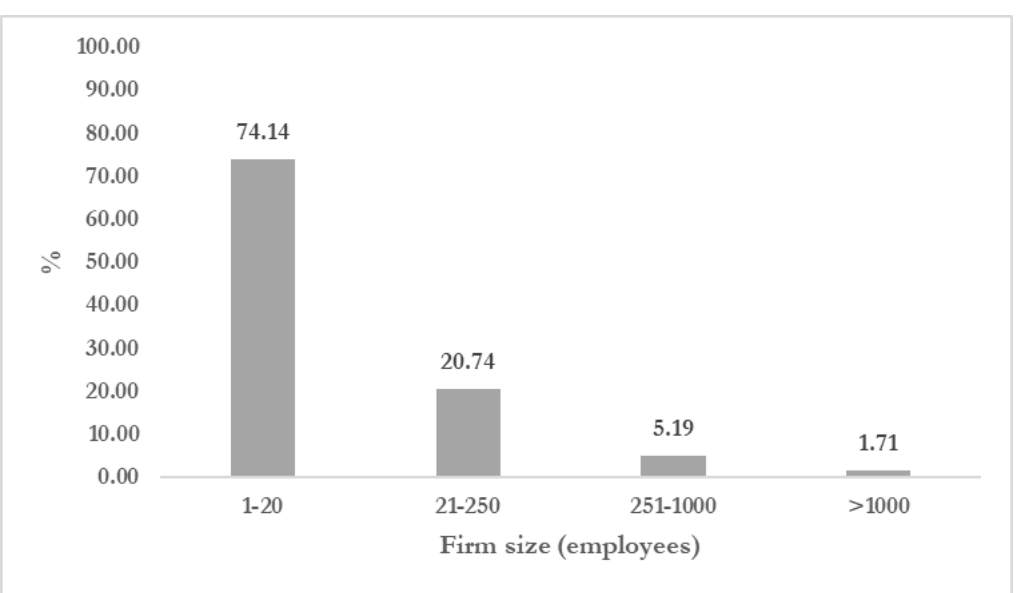

Note: The figure shows the sample distribution of ICT firms by size (number of employees) in the year 2017.

Figure 2: Patent grants by firm size in the ICT sector

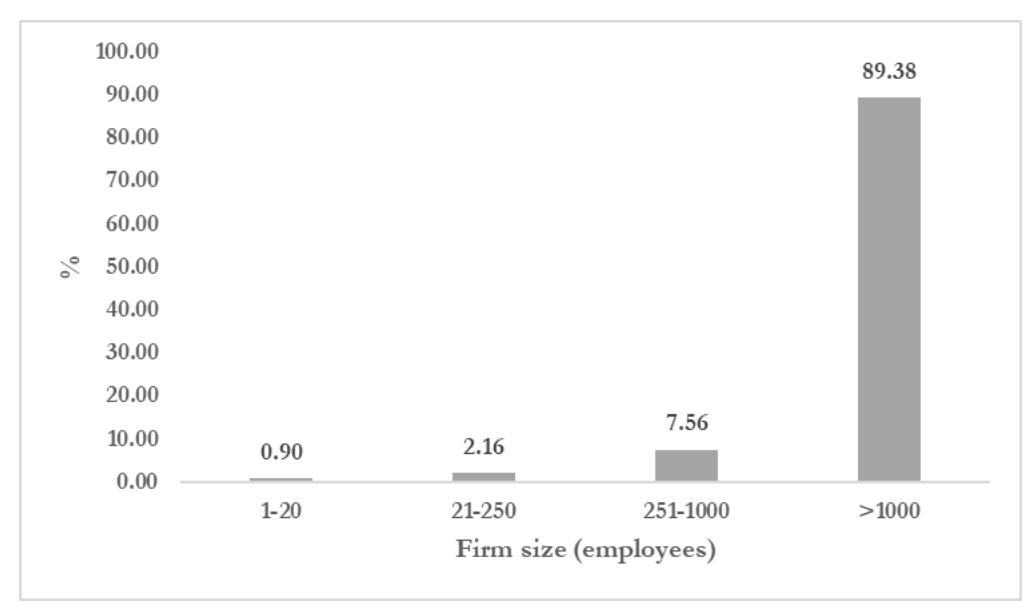

Note: The figure shows the distribution of patent grants as obtained by ICT firms in the period 2009-2017, in percentage by class of firm size. Firm size is measured as the number of employees in 2017.

Patenting activity is, at the same time, a sparse and concentrated phenomenon that involves only a few companies in the ICT industry. Such a piece of evidence motivates the following analyses to qualify how the patent assignees look different from nonassignee, where they are, and what is the impact of patent grants on their firm-level outcomes. Let us start in Figure 3 to check where most active patentees are. After we adopt the same classification by firm size of previous figures, we report on the $\mathrm{x}$-axis the average number of grants that a firm obtained in the period 2009-2017. 
Figure 3: Patents, firm size, and geography

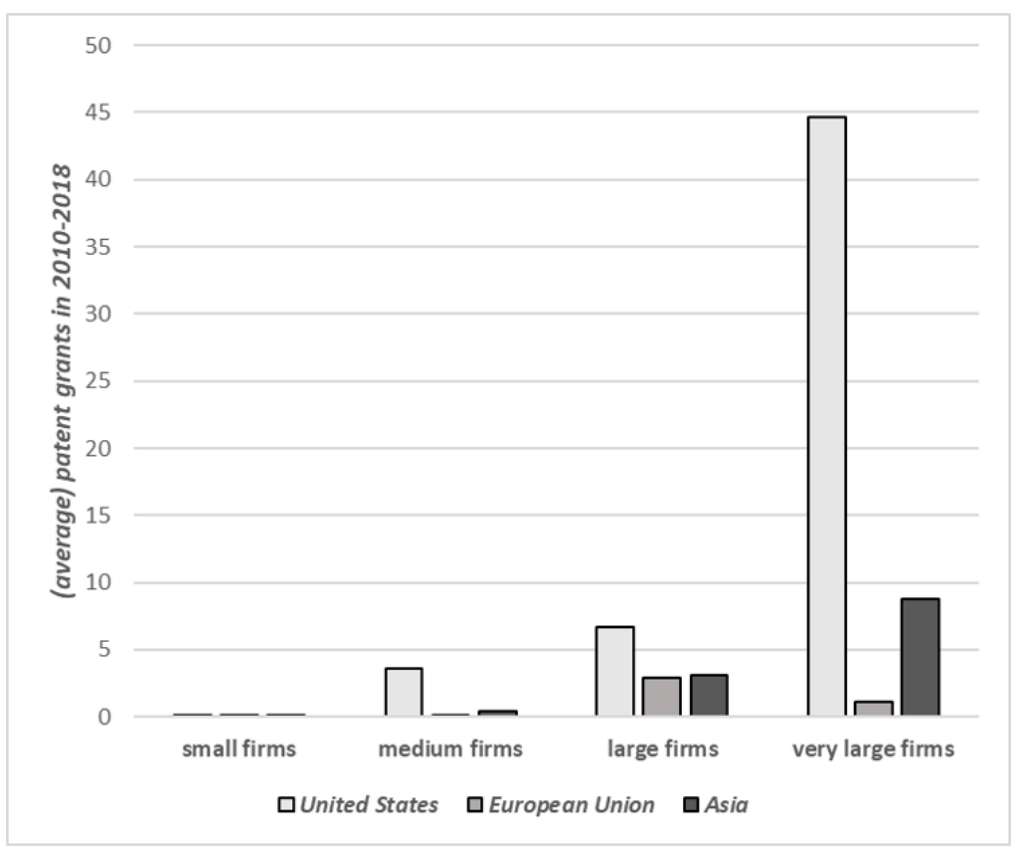

Note: The figure shows the average number of granted patents by firm size and main geographic area in our period of analyses (2009-2017). Small firms are companies with up to 20 employees; medium firms with up to 250 employees; large firms with up to 1,000 employees; very large firms witch more than 1,000 employees.

What we find is that headquarters of the most active assignees are located first and foremost by very large firms in the U.S., although very large firms with headquarters in Asia do obtain, on average, a relatively high number of patent grants, certainly higher than in the case of companies in the European Union.

Therefore, from our perspective, it is interesting to check whether and how assignees are statistically different from non-assignees. In Table 2, we provide preliminary evidence on the differences in firm-level outcomes with t-tests. What we observe is that patent assignees have, on average, a much higher market share; they are significantly more productive, bigger and more capital-intensive than non-assignee. Yet, we do not observe a significant difference in profits as measured by ROCE (Return on Capital Employed $)^{6}$. The average assignee generates about 207,000 dollars per worker in a year, whereas non-assignees register on average about 68,740 dollars per worker in a year. The representative assignee generates about 7 million dollars while average annual revenues are about 0.5 million dollars when a company is not granted any patent.

\footnotetext{
${ }^{6}$ Please note that we make our results robust to different definitions of profitability, both here and in the following paragraphs. Robustness checks on profitability are available upon request.
} 
Table 2: Firm-level outcomes of patent assignees and non-assignees

\begin{tabular}{lccccc}
\hline \hline & & & & & \\
& & & & & \\
& & & & & \\
Assignees & .0199 & 12.1624 & 17.6055 & 11.2350 & 0.0050 \\
& $(.0009)$ & $(.0068)$ & $(0.0158)$ & $(0.0098)$ & $(0.0023)$ \\
Non-assignees & .0004 & 11.1296 & 13.1669 & 8.8648 & 4.7349 \\
& $(.0001)$ & $(.0014)$ & $(0.0024)$ & $(0.0023)$ & $(4.6573)$ \\
Difference & $.0195^{* * *}$ & $1.0329^{* * *}$ & $4.4386^{* * *}$ & $2.3701^{* * *}$ & -4.7299 \\
& $(.0002)$ & $(.0085)$ & $(0.01469)$ & $(0.0141)$ & $(27.8492)$ \\
& & & & & \\
\hline
\end{tabular}

Note: The table reports t-tests on the differences in market share, (log) labour productivity, $(\log )$ size, ( $\log$ ) capital intensity and profitability (ROCE) for companies having at least one patent vis á vis companies without patents. The unit of observation is firm-year level. Clustered standard errors in parentheses. ${ }^{* * *}$ denotes significance at $1 \%$.

Eventually, to check how our main outcomes of interest correlate with the intensity of patenting activity, we also perform a basic least-squares regression model as follows:

$$
y_{i c t}=\beta_{0}+\beta_{1} P a t_{i c t}+\beta_{2} X_{i c t}+\gamma_{i}+\delta_{c t}+\epsilon_{i c t}
$$

where $y_{i t}$ is the logarithm of the $i$ th firm's outcome observed in country $c$ at time $t$, The main coefficient of interest is the one on the flows of granted patents, which we indicate with $\mathrm{Pat}_{i t}$. $X_{i c t}$ includes a set of firm-level controls. As we have a large number of firms without any patent, and the distribution of the number of patents is highly skewed, we scale the latter using the hyperbolic sine transformation $(\ln (x+$ $\left.\sqrt{x^{2}+1}\right)$, which allows approximating to the natural logarithms of the same variables while allowing retaining the zeros (Bellemare and Wichman, 2020). $X_{i c t}$ is a vector of firm-level controls, including (logs of) the number of employees, capital intensity, and the age of the company. $\gamma_{i}$ indicates a full set of firm fixed-effects; $\delta_{c t}$ are country-peryear fixed effects controlling for institutional characteristics and business cycles.

Results show that a higher degree of patenting activity is always associated with positive firm-level outcomes. Firms that obtain patents have a relatively higher market share; they are more productive, bigger, and more capital-intensive. Most interestingly, the number of patent grants per se does not correlate with higher profits, as indicated by the non-significant coefficient on ROCE. We will comment further in the following paragraphs on the latter evidence when we will show how the lack of correlations with profits is confirmed after more sophisticated empirical strategies. In Appendix, we also report results after we control for a different definition of the corporate perimeter by 
including in the analyses the patents obtained by controlled subsidiaries. The main tenets are robust and confirm the correlations observed in Figure 3.

Table 3: Firm-level outcomes and number of patents. Correlations.

\begin{tabular}{lccc}
\hline Variable & Coeff. & st. error & N. obs. \\
\hline \hline Market share & $.043^{* * *}$ & $(.006)$ & 931,613 \\
Labor productivity & $.043^{* * *}$ & $(.006)$ & 931,613 \\
Firm size & $.083^{* * *}$ & $(.007)$ & 931,613 \\
Capital intensity & $.068^{* * *}$ & $(.006)$ & 931,613 \\
ROCE (levels) & 2.961 & $(3.080)$ & 884,051
\end{tabular}

Note: Each coefficient is the result of a least-square regression of the firm-level outcome (by row) vis á vis the number of patents granted each year. We scale the number of patents by using the hyperbolic sine transformation $\left(\ln \left(x+\sqrt{x^{2}+1}\right)\right)$, which allows approximating to the natural logarithm while retaining the zeros (Bellemare and Wichman, 2020). Firm-level controls, firm-level fixed effects, and country-year fixed effects are included. Standard errors are clustered at the firm level. ${ }^{* * *}$ stands for $p<0.01$.

Clearly, positive correlations in Table 3 do not say which comes first: whether it is the case that bigger and more productive firms are the ones that are more able to obtain patents or whether it's patent grants that allow them to gain market shares and become more productive. On the other hand, it is also possible that previous positive correlations are spurious, as both firms' outcomes and ability to get patents likely correlate with the unobserved innovative content of the registered inventions. The following paragraphs will fundamentally challenge reverse causality first and then develop a strategy to unveil the endogenous relationships between firm-level outcomes, IPR protection, and innovation abilities.

\section{Empirical strategy and results}

Our objective is to assess the impact of patenting on the ICT firm-level outcomes that are of interest to us because they provide useful information on the evolution of the industry. A firm's market share and its profits are basic and straight indicators of market power, whereas productivity is often a target for competition-oriented policies. 
One assumes that if markets function properly, then consumers can benefit from the efficiency and productivity of firms. For our purpose, we adopt:

- An empirical setup for a difference-in-difference strategy introduced by Callaway and Sant'Anna (2021), which allows treatment to occur at different moments on the timeline. Basically, the authors show that common two-way fixed effects estimators are biased in the presence of a panel dimension. The intuition is that a bias occurs when newly treated units in one period are compared to units that had already been treated in a previous period. In the following paragraphs, we introduce notation to clarify how the identification strategy works, and then we report the main findings.

- A novel instrumental variable (IV) approach that considers the decision of patenting as endogenous, for which we take inspiration from Farre-Mensa et al. (2020), by using information about the propensity to grant patents at patent offices. In our case, the intuition is that we can exploit exogenous variation on the propensity to grant a patent to non-ICT firms, whose market outcomes are not correlated with the ones of the ICT industry.

\subsection{The effects of patent grants}

At this stage, we implement a difference-in-difference on a panel data set following Callaway and Sant'Anna (2021) to identify the average treatment effect on the treated (ATT) for any group of firms $g$ that obtained at least a grant at a specific time $t$, as follows:

$$
\operatorname{ATT}(g, t)=\mathbb{E}\left[\left(\frac{G_{g}}{\mathbb{E}\left[G_{g}\right]}-\frac{\frac{p_{g}(X) C}{1-p_{g}(X)}}{\mathbb{E}\left[\frac{p_{g}(X) C}{1-p_{g}(X)}\right]}\right)\left(Y_{t}-Y_{g-1}-m_{g, t}(X)\right)\right]
$$

where $G_{g}$ is a binary variable equal to one if a firm belongs to the group $g$; $C$ is a binary equal to one for firms that have never been granted a patent at any time period; $Y_{t}$ is the firms' outcome at time $t$, i.e., market share, labour productivity, firm size, capital intensity or profits (ROCE). Then, $p_{g}(X)=P\left(G_{g}=1 \mid X, G_{g}+C=1\right.$ ) is the probability of publishing a granted patent at time $g$ conditional on pre-treatment covariates $X$ and: i) either belonging in the group $g$; ii) or not being granted any patent at any time during the period. Then, $m_{g, t}(X)=\mathbb{E}\left[Y_{t}-Y_{g-1} \mid X, C=1\right]$ is the population 
outcome regression for the control group made by firms that have never been granted a patent in our period of analyses ${ }^{7}$.

Importantly, we always check that the assumption of parallel trends is made conditional on companies' characteristics before treatment. Precisely, we control for the capital intensity, the number of employees, firm age, 2-digit NACE rev. 2 industrylevel dummies, and three location-specific fixed effects for headquarters located in the European Union, the United States, and the rest of the world.

Please note that, for this exercise to work, we must consider a balanced panel with complete information on labour productivity, employment, capital intensity and age. Thus, we exclude companies that registered patents in 2009 because we cannot check for what happens before treatment in that year. Eventually, we end up with a reduced sample of 24,523 firms, of which only 432 companies have been treated at some point in 2010-2017, and 24,091 have never been granted any patents in the same period ${ }^{8}$.

At this point, to estimate the overall impact of patenting on firm-level outcomes, we shall consider a weighted average of previously defined $\operatorname{ATT}(g, t)$ in the following way:

$$
\theta_{s}^{O}=\sum_{g=2}^{T} \theta_{s}(g) P(G=g)
$$

where,

$$
\theta_{s}(g)=\frac{1}{T-g+1} \sum_{g=2}^{T} \mathbf{1}\{g \leq t\} \operatorname{ATT}(g, t)
$$

and $T$ denotes the number of years. In other words, even if we work on a panel data set, where firms can be granted patents at different moments on the timeline, we can still obtain a unique parameter, $\theta_{s}^{O}$, which tells us whether patents have an impact on firm-level outcomes. That parameter is finally a weighted average of timespecific parameters, as the latter are obtained considering groups of firms that have been treated in any observed period. The group-specific weights, $P(G=g)$ 's, are obtained

\footnotetext{
${ }^{7}$ Please note that Callaway and Sant'Anna (2021) provide alternative specifications to estimate group-time average treatment effects. In this application, we adopt the doubly robust estimator first proposed by Sant'Anna and Zhao (2020), because it is more challenging on identification than the alternatives.

${ }^{8}$ Please note that at this stage, we consider only patents granted directly to firms. In a robustness check reported in the Appendix Table A6, we repeat the exercises by considering also treated those firms that were granted patents indirectly because they were held by one of their subsidiaries in the corporate perimeter. Results do not significantly change.
} 
considering the relevance of each group over the total sample.

Finally, we can test the persistence of the effect thanks to a classical event study analysis, for which we need to compute the length of exposure to the treatment, $e$. The latter is another form of aggregation of the group-time specific effect, which we can define as:

$$
\theta_{e s}(e)=\sum_{g=2}^{T} \mathbf{1}\{g+e \leq T\} P(G=g \mid G+e \leq T) \operatorname{ATT}(g, g+e)
$$

In plain words, eq. 4 returns the average impact on firm-level outcomes after $e$ periods from being granted a patent, considering the heterogeneity across all cohorts participating in the treatment.

In Table 4, we report estimates of the impact of patenting activity on firm-level outcomes. According to our findings, companies being granted patents in the period 2010-2017 benefit from an increase in market share by $9.2 \%$ (log units: 0.088 ), which comes with a parallel increase in revenues (9.1\%; log units: 0.087$)$, as largely expected. Indeed, patents by ICT firms are mainly devoted to the protection of product innovations. Firms ask for the protection of new technological advancements that improve the products that they professionally sell. In this case, we argue that it makes sense that we detect an impact on market shares and firm size, thanks to higher revenues derived after IPR protection. We cannot exclude that firms in sectors different from ICT can derive a significant benefit from grants in productivity.

Yet, considering the heterogeneity in the distributions of both firm size and patenting activity observed before (Figures 1 and 2), it makes sense to check if the impact on smaller patentees is significantly different from the impact on bigger corporate players. In the second and third sections of Table 4, we split the sample of firms considering the size (measured by revenues) before the treatment. We consider smaller firms the ones that report revenues below the sample median, and we separate them from bigger firms as they record revenues above the sample median. 
Table 4: The effects of patent grants on firm-level outcomes: ATT

\begin{tabular}{lcccc}
\hline Variable & $\theta_{s}^{O}$ & s. e. & No. of treated firms & No. of untreated firms \\
\hline \hline All firms & & & & \\
$(\log )$ Market share & $0.088^{* * *}$ & $(0.029)$ & 432 & 24,091 \\
$(\log )$ Labor productivity & -0.001 & $(0.022)$ & 432 & 24,091 \\
$(\log )$ Firm size & $0.087^{* * *}$ & $(0.030)$ & 432 & 24,091 \\
$(\log )$ Capital intensity & 0.036 & $(0.042)$ & 432 & 24,091 \\
ROCE (levels) & -0.015 & $(0.014)$ & 330 & 18,332 \\
\hline
\end{tabular}

\begin{tabular}{|c|c|c|c|c|}
\hline (log) Market share & $0.274^{* * *}$ & $(0.091)$ & 71 & 12,191 \\
\hline (log) Labor productivity & 0.064 & $(0.073)$ & 71 & 12,191 \\
\hline$(\log )$ Firm size & $0.268^{* * *}$ & $(0.092)$ & 71 & 12,191 \\
\hline (log) Capital intensity & 0.121 & $(0.119)$ & 71 & 12,191 \\
\hline ROCE (levels) & 0.004 & $(0.046)$ & 50 & 9,571 \\
\hline ROCE (IHS) & -0.005 & $(0.024)$ & 50 & 9,571 \\
\hline \multicolumn{5}{|l|}{ Big firms } \\
\hline (log) Market share & 0.047 & $(0.030)$ & 361 & 11,900 \\
\hline (log) Labor productivity & -0.017 & $(0.021)$ & 361 & 11,900 \\
\hline (log) Firm size & 0.046 & $(0.028)$ & 361 & 11,900 \\
\hline (log) Capital intensity & 0.017 & $(0.042)$ & 361 & 11,900 \\
\hline ROCE (levels) & -0.009 & $(0.015)$ & 280 & 8,761 \\
\hline ROCE (IHS) & -0.008 & $(0.012)$ & 280 & 8,761 \\
\hline
\end{tabular}

Note: The table illustrates average aggregate treatment effects after following the method of Callaway and Sant'Anna (2021), in the presence of a panel setting, under the assumption of parallel trends conditional on firm-level control variables, 2-digit sector and regional dummies. Errors are clustered at the firm level. $*, * *$ and ${ }^{* * *}$ denotes significance at $10 \%, 5 \%$ and $1 \%$ respectively.

Results clearly show that the magnitude of the impact for smaller firms is quite 
relevant on both market shares (31.5\%; log units: 0.274$)$ and firm size $(30.7 \%$; log units: 0.268). Interestingly, the impact on bigger firms tested alone is never significant on any of our outcomes of interest. Bigger players in the ICT global industry do not seem to benefit from patent grants after controlling for reverse causality.

Notably, coefficients on labor productivity, capital intensity and profitability (ROCE) are never statistically significant as from Table 4. Apparently, after challenging for reverse causality, also these correlations with patenting activity observed in Table 3 fade away. In other words, our findings seem to show that bigger and more productive companies are able to get more patent grants, but their size, productivity, and profitability are not a consequence of the grants they obtained. We argue that our findings are coherent with cross-country general evidence on manufacturing companies beyond the ICT industry, as in Andrews et al. (2014). On the other hand, Balasubramanian and Sivadasan (2011) find a significant effect on productivity in the case of US firms, but relatively smaller if compared to the impact on firm size.

Eventually, we report event studies following the procedure described in eq. 4 Appendix Figures A1, A2, A3, A4, and A5. We aim to check how our main firm-level outcomes of interest evolve as time passes from when the representative company has been granted a patent. As in any classical event study, we align events on a reference period, $e=0$, which is the first year a firm has been granted a patent in our sample, $e=0$. Therefore, following eq. 4 , we are able to plot the impact on the outcome of the representative company at any following period, thereby checking that previous trends are conditional on firm-level characteristics, industry affiliations, and firm's location choices. Evidently, in any of the following figures, we do not visualize any statistically significant trend before treatment, i.e., companies are not systematically showing that they were becoming bigger, more productive, or capital intensive before obtaining IPR in $e=0$.

Please note that, at this stage, we may still confound the impact of property rights protection with the role played by innovation on firm-level outcomes. In the previous paragraphs, we do control for self-selection into the status of patentees, but we could not separate the unobserved impact of the innovative content of productive inventions on the same firms' outcomes. This is because patent grants are both an indicator that companies were able to innovate and, at the same time, that they were granted protection from imitation by competitors. In the following paragraphs, we will focus on distilling the role of property rights protection. 


\subsection{Property rights protection and firms' dynamics: an IV ap- proach}

In previous paragraphs, we first detected a positive premium on firm-level outcomes by patentees over non-patentees. Then, we implemented a check for the self-selection of firms into the status of a patentee with a difference-in-difference approach on a panel set to check for self-selection into a patentee status. We concluded that smaller patentees gain an advantage in market shares and sales after the patent grant. Still, we needed to be agnostic about the economic channel that drives that impact. Naturally, a patent grant is both an indicator of IPR protection and a proxy for the unobserved ability of firms to innovate in products or production processes. Thus, gains in market shares and firm size are expected after a grant as either the result of a higher demand for innovative ICT products or as a consequence of the protection granted by patent offices from imitation by competitors.

To focus on the role of intellectual protection of property rights, we implement in this section a novel instrumental variable strategy inspired by the work done by FarreMensa et al. (2020), who exploit the exogenous variation observed in decision-making by experts at the patent offices when they have to assess the innovative content of inventions before granting a patent.

We propose two instruments to capture the innovative content of patent grants based on the information we have about assignees of ICT technologies that operate outside the ICT industry. Our intuition for the exclusion restriction assumption is that nonICT firms do not compete with the ones in the ICT global industry; therefore, we do not expect firms' market shares and sizes to correlate across the two groups. Yet, firms in non-ICT industries occasionally are interested in protecting their ICT innovations; therefore, when they apply for a grant, they are subject to the same evaluation process regardless of the assignees' economic activity. In this sense, we expect propensities to get patent grants in the same technologies and in the same year to be correlated, and that's our intuition for the instruments' relevance assumption.

In particular, we consider:

- the approval rate of grants over the number of applications that non-ICT firms put forward in the same technologies of ICT firms, $j$, evaluated by the same patent offices, $h$, in each same year, $t$, as follows: 


$$
a p p r_{j h t}^{\text {no ICT }}=\frac{\text { grants }_{j h t}^{\text {no ICT }}}{a p p l_{j h t}^{\text {no ICT }}}
$$

- the number of applications $\left(a p p l_{j h t}^{n o} I C T\right)$ by non-ICT firms at the same patent offices, $h$, in the same technology classes, $j$, and in the same year, $t^{9}$.

Please note that to be consistent with our identification strategy sketched above, we need to limit our analyses only to smaller firms with unique patents obtained in our period of analyses. What we need to avoid is confounding effects from different technologies. If we considered bigger players that obtain grants in more technologies, we would not be able to get a relevant instrument because we would not know which approval rates to pick, having different evaluation processes to take into account ${ }^{10}$.

Eventually, the first equation of our IV approach can be written as:

$$
P(\text { grant })_{i j h t}=\phi_{1} a p p r_{j h t}^{n o I C T}+\phi_{2} a p p l_{j h t}^{n o} I C T+\Pi Z_{i j h t}+\alpha_{h}+\alpha_{s}+\alpha_{j t}+u_{i j h t}
$$

where $P(\text { grant })_{i j h t}$ is a binary indicator equal to 1 when a firm $i$ at time $t$ is granted property rights by patent office $h$ for a patent in technology class $j$. Besides the instruments mentioned above $\left(a p p r_{j h t}^{n o I C T}, a p p l_{j h t}^{n o I C T}\right)$, we also control for firm-level characteristics $Z_{i j h t}$, namely firm size, capital intensity and related growth rates, as well as firm age. $\alpha_{h}, \alpha_{s}, \alpha_{j t}$ are respectively a set of countries' patent offices, industry, and technology-year fixed effects.

Eventually, the outcome equation can be written as follows:

$$
Y_{i j h t}=\alpha_{0}+\alpha_{1} \hat{P}(\text { grant })_{i j h t}+\alpha_{2} Z_{i j h t}+\alpha_{h}+\alpha_{s}+\alpha_{j t}+v_{i j h t}
$$

where $Y_{i j c t}$ is the firm-level outcome of firm $i$ operating in year $t$, and $\hat{P}(\text { grant })_{i j h t}$ is the predicted outcome from eq. 5. Please note that, for the scope of our analysis, we perform four separate models reported in the following tables by forwarding both the outcomes, $Y_{i j t+n}$, and the firm-level covariates, $Z_{i j h t+n}$, to observe what happens in the years following the unique grant, $n=(1,2,3,4)$.

\footnotetext{
${ }^{9}$ Please note how from the application to the actual patent grant there could be a few years distance. That's why, in line with relevant literature, we consider priority years for applications and publication years for grants.

${ }^{10}$ We are aware that here we have an important limitation of our study. Our instrumental variable approach does not work in the case of bigger companies because it is difficult to find in the population of the ICT industry cases of big companies that register only one patent in our period of analyses.
} 
Eqs. 5 and 6 represent a set of simultaneous equations to be run following a classical optimal generalized method of moments (GMM) with robust standard errors. Usual tests for endogeneity are reported in the following Tables 5 and 6 , where we test separately for firm-level market shares and firm size, as the latter variables are the firm-level outcomes for which we already found a significant impact as from the analyses of the previous section. We confine non-significant results on profit margins in Appendix Table A5.

Evidently, the positive impact of patent grants on a firm's market share and size is still standing after we check for the unobserved innovative contents of ICT technologies. Magnitudes are also not distant from what we observed in Table 4 in the case of smaller firms. Hence, we can observe that most of the impact is registered just in the first period of the treatment and not after, in line with event studies already shown in Figures A1 and A3. Indeed, patentees increase their sales thanks to the new ICT products that they can launch on the market ${ }^{11}$.

In the second part of the following Tables 5 and 6 , we report the results of the eq. 5 after a linear probability model (LPM). Tests indicate that both instruments are good predictors of whether a firm is granted a patent. Both the approval rates and the total number of applications in an ICT technology-country-year cell by firms that operate in non-ICT markets are well correlated with the binary outcome. In the case of the total number of applications, the coefficient is negative and significantly associated with the odds that a company obtains a patent grant, in line with our intuition that more crowded technological classes are less innovative at the margin.

In line with previous evidence, we do not find any significant impact on profitability measured by the ROCE index. More in general, the ensemble of our findings relates to existing frameworks that study the market structure of innovative industries, as pertains the case of the ICT global firms. From our perspective, our findings hint at the existence of endogenous sunk costs á la Sutton (1998). See also Shaked and Sutton (1983, 1987). Briefly, even in the presence of an increase in market shares by relatively smaller firms, profit margins may not follow because firms have to sustain the high sunk costs in R\&D that are needed to keep up with innovation, and to meet the demand by customers for novel and differentiated ICT products.

\footnotetext{
${ }^{11}$ Please note, once again, that we do not consider in our analyses the inventions that do not belong to the ICT technologies, from which we may think that ICT firms may obtain efficiencies in production processes.
} 
Table 5: Market shares and protection of intellectual property rights: an IV approach

\begin{tabular}{|c|c|c|c|c|c|}
\hline Dependent variable: (log of) Market share & $(\mathrm{t})$ & $(\mathrm{t}+1)$ & $(\mathrm{t}+2)$ & $(t+3)$ & $(\mathrm{t}+4)$ \\
\hline$\hat{P}($ grant $)$ & $\begin{array}{c}0.26^{* *} \\
(0.12)\end{array}$ & $\begin{array}{c}0.14 \\
(0.13)\end{array}$ & $\begin{array}{c}0.23 \\
(0.14)\end{array}$ & $\begin{array}{l}0.057 \\
(0.14)\end{array}$ & $\begin{array}{c}0.37 \\
(0.19)\end{array}$ \\
\hline (log of) Firm size & $\begin{array}{l}1.07^{* * *} \\
(0.015)\end{array}$ & $\begin{array}{l}1.09^{* * *} \\
(0.015)\end{array}$ & $\begin{array}{l}1.11^{* * *} \\
(0.018)\end{array}$ & $\begin{array}{l}1.11^{* * *} \\
(0.021)\end{array}$ & $\begin{array}{l}1.16^{* * *} \\
(0.027)\end{array}$ \\
\hline Firm growth & $\begin{array}{c}-0.37^{* * *} \\
(0.042)\end{array}$ & $\begin{array}{c}-0.41^{* * *} \\
(0.057)\end{array}$ & $\begin{array}{c}-0.35^{* * *} * \\
(0.066)\end{array}$ & $\begin{array}{c}-0.26^{* * *} \\
(0.068)\end{array}$ & $\begin{array}{l}-0.16^{* *} \\
(0.072)\end{array}$ \\
\hline (log of) Capital intensity & $\begin{array}{c}0.15^{* * *} \\
(0.015)\end{array}$ & $\begin{array}{c}0.14^{* * *} \\
(0.014)\end{array}$ & $\begin{array}{c}0.16^{* * *} \\
(0.014)\end{array}$ & $\begin{array}{c}0.16^{* * *} \\
(0.017)\end{array}$ & $\begin{array}{c}0.19^{* * *} \\
(0.020)\end{array}$ \\
\hline Capital intensity growth & $\begin{array}{l}-0.013 \\
(0.027)\end{array}$ & $\begin{array}{c}-0.12^{* * * *} \\
(0.031)\end{array}$ & $\begin{array}{l}-0.063 \\
(0.047)\end{array}$ & $\begin{array}{l}-0.028 \\
(0.040)\end{array}$ & $\begin{array}{c}-0.087^{* *} \\
(0.035)\end{array}$ \\
\hline Firm age & $\begin{array}{c}0.011^{* * *} \\
(0.0020)\end{array}$ & $\begin{array}{c}0.0058^{* * *} \\
(0.0019)\end{array}$ & $\begin{array}{c}0.0056^{* *} \\
(0.0024)\end{array}$ & $\begin{array}{c}0.0030 \\
(0.0027) \\
\end{array}$ & $\begin{array}{c}-0.0086^{* * *} \\
(0.0031) \\
\end{array}$ \\
\hline \multicolumn{6}{|l|}{ Dependent variable: $P($ grant $): Y e s=1$} \\
\hline & $(\mathrm{t})$ & $(\mathrm{t}+1)$ & $(\mathrm{t}+2)$ & $(t+3)$ & $(t+4)$ \\
\hline Approval rate non-ICT firms & $\begin{array}{c}0.52^{* * *} \\
(0.025)\end{array}$ & $\begin{array}{c}0.55^{* * *} \\
(0.035)\end{array}$ & $\begin{array}{c}0.47^{* * *} \\
(0.040)\end{array}$ & $\begin{array}{c}0.52^{* * *} \\
(0.050)\end{array}$ & $\begin{array}{c}0.55^{* * *} \\
(0.057)\end{array}$ \\
\hline Total applications non-ICT firms & $\begin{array}{c}-0.030 * * * \\
(0.0040)\end{array}$ & $\begin{array}{c}-0.032^{* * *} \\
(0.0047)\end{array}$ & $\begin{array}{c}-0.040^{* * *} \\
(0.0049)\end{array}$ & $\begin{array}{c}-0.044^{* * *} \\
(0.0061)\end{array}$ & $\begin{array}{c}-0.040^{* * *} \\
(0.0078)\end{array}$ \\
\hline (log of) Firm size & $\begin{array}{c}-0.015^{* *} \\
(0.0058)\end{array}$ & $\begin{array}{c}-0.014^{* *} \\
(0.0061)\end{array}$ & $\begin{array}{c}-0.015^{* *} \\
(0.0068)\end{array}$ & $\begin{array}{c}-0.011 \\
(0.0085)\end{array}$ & $\begin{array}{l}-0.012 \\
(0.010)\end{array}$ \\
\hline Firm growth & $\begin{array}{l}0.0043 \\
(0.012)\end{array}$ & $\begin{array}{c}0.027 \\
(0.020)\end{array}$ & $\begin{array}{c}0.058^{* *} \\
(0.025)\end{array}$ & $\begin{array}{c}0.037 \\
(0.035)\end{array}$ & $\begin{array}{c}-0.087^{* * *} \\
(0.031)\end{array}$ \\
\hline (log of) Capital intensity & $\begin{array}{c}-0.016^{* * *} \\
(0.0054)\end{array}$ & $\begin{array}{c}-0.016^{* * *} \\
(0.0059)\end{array}$ & $\begin{array}{l}-0.0051 \\
(0.0065)\end{array}$ & $\begin{array}{l}-0.0094 \\
(0.0073)\end{array}$ & $\begin{array}{c}-0.018^{* *} \\
(0.0082)\end{array}$ \\
\hline Capital intensity growth & $\begin{array}{c}-0.011 \\
(0.0093)\end{array}$ & $\begin{array}{c}0.015 \\
(0.012)\end{array}$ & $\begin{array}{l}-0.015 \\
(0.015)\end{array}$ & $\begin{array}{c}0.013 \\
(0.019)\end{array}$ & $\begin{array}{c}0.018 \\
(0.019)\end{array}$ \\
\hline Firm age & $\begin{array}{c}0.00017 \\
(0.00089)\end{array}$ & $\begin{array}{l}-0.00012 \\
(0.00091)\end{array}$ & $\begin{array}{l}0.00082 \\
(0.0011)\end{array}$ & $\begin{array}{c}0.0034^{* *} \\
(0.0014)\end{array}$ & $\begin{array}{c}0.0043^{* *} \\
(0.0018)\end{array}$ \\
\hline N. obs. & 4937 & 3568 & 2610 & 1933 & 1421 \\
\hline R-squared & 0.729 & 0.750 & 0.777 & 0.734 & 0.748 \\
\hline Adjusted R-squared & 0.711 & 0.727 & 0.753 & 0.700 & 0.712 \\
\hline AIC & 12412.7 & 9051.9 & 6312.0 & 4737.1 & 3303.2 \\
\hline Hansen's J test & 11.45 & 8.08 & 1.12 & 2.88 & 0.76 \\
\hline LM test statistics & 402.7 & 283.8 & 211.5 & 183.5 & 139.3 \\
\hline
\end{tabular}

Note: The table illustrates the impact of a patent grant on firm-level market shares (outcome equation) after an IV approach that controls (first stage) the endogenous role of innovation contents after exogenous variation on assignees in non-ICT industries that innovate in the same technologies and the same year of ICT firms. At the bottom of the table, we record tests on the weakness of instruments. Estimates are obtained after an optimal GMM estimation with robust standard errors in parentheses. ${ }^{*} \mathrm{p}<0.1 ;{ }^{* *} \mathrm{p}<0.05 ;{ }^{* * *} \mathrm{p}<0.01$. 
Table 6: Firm size and protection of intellectual property rights: an IV approach

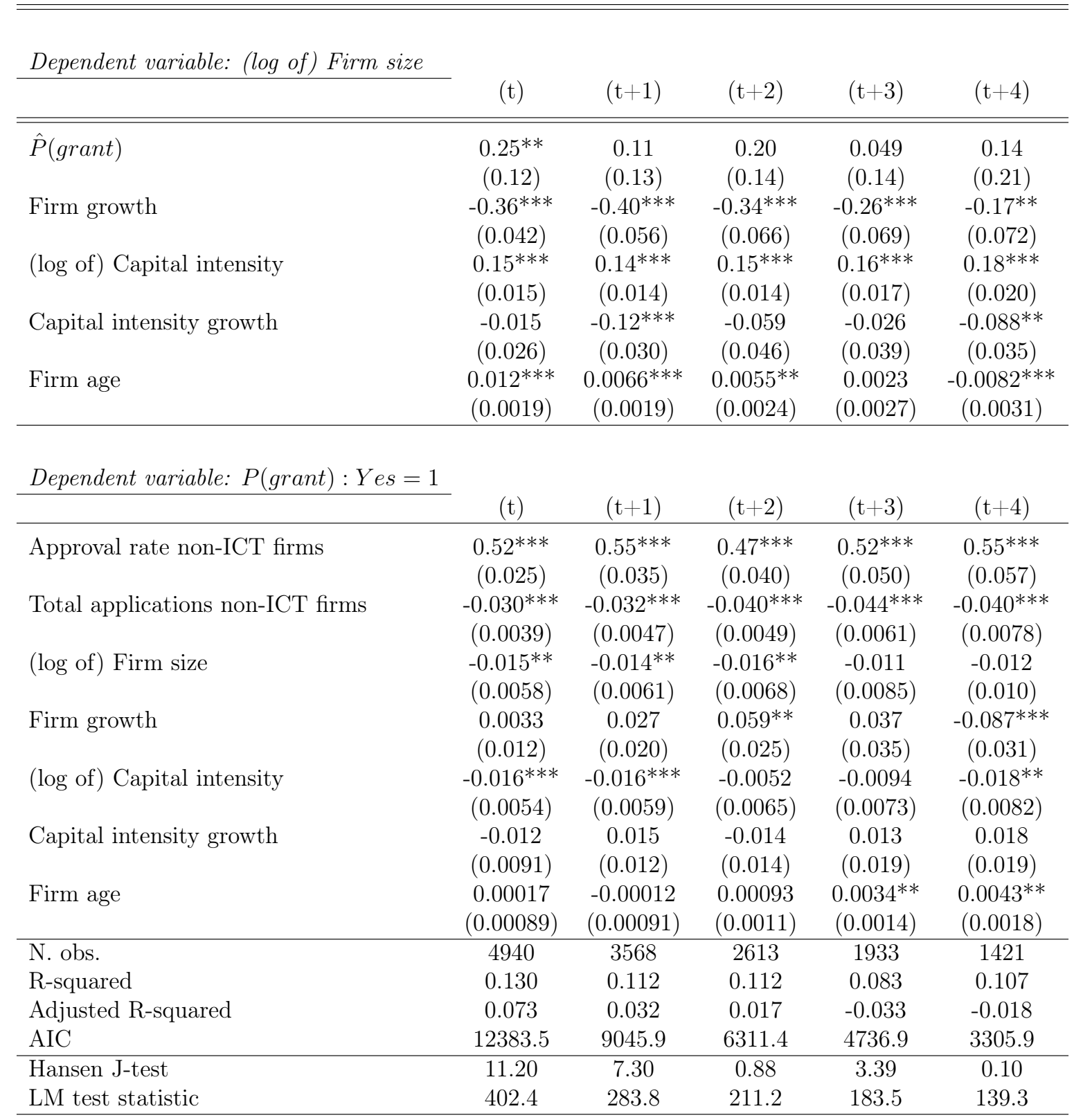

Note: The table illustrates the impact of a patent grant on firm-level market shares (outcome equation) after an IV approach that controls (first stage) the endogenous role of innovation contents after exogenous variation on assignees in non-ICT industries that innovate in the same technologies and the same year of ICT firms. At the bottom of the table, we record tests on the weakness of instruments. Estimates are obtained after an optimal GMM estimation with robust standard errors in parentheses. ${ }^{*} \mathrm{p}<0.1 ;{ }^{* *} \mathrm{p}<0.05 ;{ }^{* * *} \mathrm{p}<0.01$. 


\section{Robustness and sensitivity checks}

In this Section, we comment on a few robustness and sensitivity checks whose results are reported in Appendix Tables.

First, we check whether the corporate perimeter matters for the magnitude and significance of the impact of patent grants. As we have an industry with global outreach, we cannot exclude that innovation and patenting activity are delegated to subsidiaries located in the same country of headquarters or abroad. The main idea is that multinational companies can control important portfolios of patents and manage them through subsidiaries located in many countries. In bigger groups, considerations about fiscal optimization and local knowledge advantages can bring about the location of highly specialized R\&D labs abroad(Bösenberg and Egger, 2017; Alstadsæter et al., 2018; Davies et al., 2020).

For our purpose, we modified our treatment group to consider as also treated those companies whose subsidiaries have been granted a patent in our period of analysis. In the second column of Appendix Table 6, we visualize the change in the composition of the treatment group. On the other hand, the control group will encompass companies without patents, either at the headquarter or subsidiary levels. We show in Appendix Tables A6 and A7 how the main tenets on market shares and firm size are confirmed.

A second concern that we address relates to the computation of market shares. We perform a sensitivity analysis to check whether previous results were mediated exclusively by firms' demography since both market entry and exit dynamics may correlate with both innovation abilities and the level of property rights protection. In other words, it is possible that the dynamics of IPR interact with market selection processes. Thus, some firms may find it difficult to outlive the market after competitors have been granted the use of fundamental innovations. On the other hand, new entrants may find it convenient to enter into the market when a patent grant expires after they have the chance to imitate fundamental products. To be sure that changing barriers to entry are not driving our previous results, we repeat our previous exercises by computing market shares on a balanced sample, i.e., considering only incumbent firms for which we can estimate market shares within the sample, excluding entry and exit dynamics. Results are reported in Appendix Table A8. The coefficient of interest in the first year after the grant is still positive and significant, with a magnitude slightly lower than in baseline results.

A third concern relates to the geographical composition of the sample. Although 
we perform our tests on ICT companies located in 39 countries, we find that there is an uneven concentration of companies across countries. The composition of our sample is prima facie consistent with what we know about the geographical concentration of the global ICT industry. Countries like the United States, Japan and South Korea host headquarters of important global market players. On the other hand, in section 3 , we showed how countries of the European Union present a relatively lower competitive advantage in the ability to patent innovations. Although the EU hosts an important number of companies in the ICT industry, these companies have a relatively lower propensity to obtain patent grants. Informed by previous evidence, we repeat our exercises on market shares by separating two subsets. In Table A9, we provide results

for companies in the United States, Japan and South Korea, whereas the impact on European firms is registered in Table A10. Please note how our results are indeed sensitive to geographic location. When we consider only the US, Japan and South Korea, the impact on market shares is bigger and more persistent up to the third year after the publication of the grant.

\section{Conclusions}

The global ICT industry is a fundamental source of growth in modern economies. Its products and services are purchased by final consumers who want to upgrade and update on the newest technologies; they are also important inputs in the production processes of many other sectors.

Comprehensibly, the sector attracts the attention of both policymakers and scholars from different fields. Most recently, serious doubts have been raised about an excessive market concentration among a few Big-Tech global players. Antitrust authorities in the US and the European Union continue to investigate whether there is evidence of detrimental effects on social welfare. In this context, we may reconnect with the more general debate about the costs and benefits of the present IPR regimes.

Specifically, in this contribution, we test the direction of causality from patenting activity to firm-level outcomes, namely market shares, productivity, firm size, and profit margins. We adopt a composite empirical strategy that concludes that only smaller firms that are granted patents can benefit from a short-run increase in market shares and size, thanks to the possibility of selling innovative products on the market. We do not find significant evidence that firm-level outcomes of already big companies are 
ex-post affected by grants.

Yet, for all their efforts, patentees of any firm size do not seem to obtain higher profit margins because of patent grants. On the contrary, we observe that most active patentees are financially distressed once we look at their capital returns.

When we challenge our results to distil the effect of protecting intellectual property rights from the unobserved innovation contents of inventions, we find that most of the impact on market shares and firm size for smaller firms comes from the first. That is,

Eventually, we discuss how our results point to endogenous sunk costs in the ICT global industry, in line with the framework originally proposed by Sutton (1991). In this case, ICT companies have to invest heavily in R\&D to catch up with competitors and keep consumers willing to pay for the latest innovative features of products that are made available on the market.

In our view, there are important avenues of studies that could help understanding better the relationship between IPR protection, market power and social welfare. As far as we know, the literature on market competition still has some open challenges that need to be considered. For example, Berry et al. (2019) highlighted that empirical studies focusing on firms' market power suffer from both empirical and theoretical limitations, especially those considering markups as a proxy for market power.

Among others, we would be interested in studying whether different IPR regimes associate with different efficiency and welfare dynamics, starting from the heterogeneity observed between companies operating in the European Union and those from the United States. 


\section{References}

Acemoglu, D., Autor, D., Dorn, D., Hanson, G. H., Price, B., May 2014. Return of the solow paradox? it, productivity, and employment in us manufacturing. American Economic Review 104 (5), 394-99.

Acs, Z. J., Audretsch, D. B., 1988. Innovation in large and small firms: an empirical analysis. The American economic review, 678-690.

Aghion, P., Bloom, N., Blundell, R., Griffith, R., Howitt, P., 2005. Competition and innovation: An inverted-U relationship. The quarterly journal of economics 120 (2), 701-728.

Alstadsæter, A., Barrios, S., Nicodème, G., Skonieczna, A. M., Vezzani, A., 2018. Patent boxes design, patents location, and local R\&D. Economic Policy 33 (93), $131-177$.

Andrews, D., Criscuolo, C., Menon, C., 2014. Do resources flow to patenting firms?: Cross-country evidence from firm level data. OECD Economics Department Working Papers (1127).

Balasubramanian, N., Sivadasan, J., 2011. What happens when firms patent? new evidence from US economic census data. The Review of Economics and Statistics 93 (1), 126-146.

Bellemare, M. F., Wichman, C. J., 2020. Elasticities and the inverse hyperbolic sine transformation. Oxford Bulletin of Economics and Statistics 82 (1), 50-61.

Benages, E., Hernández, L., Mínguez, C., Pérez, J., Robledo, J., Salamanca, J., Solaz, M., Cardona, M., López-Cobo, M., Righi, R., Samoili, S., 2018. The 2018 PREDICT dataset methodology. Tech. rep., Joint Research Centre, European Commission, https://ec. europa.eu/jrc/sites/jrcsh/files/jrc111922.pdf.

Berry, S., Gaynor, M., Morton, F. S., 2019. Do increasing markups matter? lessons from empirical industrial organization. The Journal of Economic Perspectives 33 (3), $44-68$.

Bloom, N., Van Reenen, J., 2002. Patents, real options and firm performance. The Economic Journal 112 (478), C97-C116.

Blundell, R., Griffith, R., Van Reenen, J., 1999. Market share, market value and innovation in a panel of British manufacturing firms. The review of economic studies 66 (3), 529-554.

Boldrin, M., Levine, D. K., 2008. Against intellectual monopoly. Cambridge University Press Cambridge. 
Boldrin, M., Levine, D. K., February 2013. The case against patents. Journal of Economic Perspectives 27 (1), 3-22.

Brynjolfsson, E., Hitt, L. M., 2003. Computing productivity: Firm-level evidence. Review of economics and statistics 85 (4), 793-808.

Bösenberg, S., Egger, P. H., 01 2017. R\&D tax incentives and the emergence and trade of ideas. Economic Policy 32 (89), 39-80.

Callaway, B., Sant'Anna, P. H., 2021. Difference-in-differences with multiple time periods. Journal of Econometrics 225 (2), 200-230.

Cimoli, M., Dosi, G., Maskus, K. E., Okediji, R. L., Reichman, J. H., Stiglitz, J. E., 2014. Intellectual property rights: legal and economic challenges for development. Oxford University Press.

Cravino, J., Levchenko, A. A., 2016. Multinational Firms and International Business Cycle Transmission*. The Quarterly Journal of Economics 132 (2), 921-962.

Crespi, G., Zuniga, P., 2012. Innovation and productivity: Evidence from six latin american countries. World Development 40 (2), 273-290.

Davies, R. B., Kogler, D. F., Hynes, R., 2020. Patent boxes and the success rate of applications. CESifo Working Paper No. 8375.

Del Prete, D., Rungi, A., 2017. Organizing the global value chain: A firm-level test. Journal of International Economics 109, 16-30.

Dosi, G., Marengo, L., Pasquali, C., 2006. How much should society fuel the greed of innovators?: On the relations between appropriability, opportunities and rates of innovation. Research Policy 35 (8), 1110-1121.

Driffield, N., Love, J. H., Yang, Y., 2016. Reverse international knowledge transfer in the MNE:(where) does affiliate performance boost parent performance? Research Policy 45 (2), 491-506.

Farre-Mensa, J., Hegde, D., Ljungqvist, A., 2020. What is a patent worth? evidence from the us patent "lottery". The Journal of Finance 75 (2), 639-682.

Fattorini, L., Ghodsi, M., Rungi, A., 2020. Cohesion policy meets heterogeneous firms. JCMS: Journal of Common Market Studies 58 (4), 803-817.

Geroski, P. A., Pomroy, R., 1990. Innovation and the evolution of market structure. The journal of industrial economics, 299-314.

Gopinath, G., Kalemli-Ozcan, S., Karabarbounis, L., Villegas-Sanchez, C., 2017. Capital Allocation and Productivity in South Europe. The Quarterly Journal of Economics 132 (4), 1915-1967. 
Graham, S., Vishnubhakat, S., 2013. Of smart phone wars and software patents. Journal of Economic Perspectives 27 (1), 67-86.

Griffith, R., Huergo, E., Mairesse, J., Peters, B., 12 2006. Innovation and Productivity Across Four European Countries. Oxford Review of Economic Policy 22 (4), 483-498.

Haskel, J., Westlake, S., 2018. Capitalism without Capital: The Rise of the Intangible Economy. Princeton University Press.

Henry, C., Stiglitz, J. E., 2010. Intellectual property, dissemination of innovation and sustainable development. Global Policy 1 (3), 237-251.

Kalemli-Ozcan, S., Sorensen, B., Villegas-Sanchez, C., Volosovych, V., Yesiltas, S., 2015. How to construct nationally representative firm level data from the orbis global database. Tech. rep., National Bureau of Economic Research.

Kline, P., Petkova, N., Williams, H., Zidar, O., 03 2019. Who Profits from Patents? Rent-Sharing at Innovative Firms*. The Quarterly Journal of Economics 134 (3), 1343-1404.

Mairesse, J., Robin, S., 2009. Innovation and productivity: a firm-level analysis for french manufacturing and services using CIS3 and CIS4 data (1998-2000 and 20022004). Paris: CREST-ENSAE.

Mohnen, P., Hall, B. H., 2013. Innovation and productivity: An update. Eurasian Business Review 3 (1), 47-65.

Moser, P., February 2013. Patents and innovation: Evidence from economic history. Journal of Economic Perspectives 27 (1), 23-44.

Nambisan, S., Wright, M., Feldman, M., 2019. The digital transformation of innovation and entrepreneurship: Progress, challenges and key themes. Research Policy 48 (8), 103773.

Noailly, J., Smeets, R., 2015. Directing technical change from fossil-fuel to renewable energy innovation: An application using firm-level patent data. Journal of Environmental Economics and Management 72, 15-37.

Sant'Anna, P. H., Zhao, J., 2020. Doubly robust difference-in-differences estimators. Journal of Econometrics 219 (1), 101-122.

Shaked, A., Sutton, J., 1983. Natural oligopolies. Econometrica 51 (5), 1469-1483.

Shaked, A., Sutton, J., 1987. Product differentiation and industrial structure. The Journal of Industrial Economics 36 (2), 131-146.

Skeie, Ø. B., Johansson, A., Menon, C., Sorbe, S., 2017. Innovation, patent location and tax planning by multinationals. OECD Economics Department Working Pa- 
pers (1360).

Sutton, J., 1986. Vertical product differentiation: Some basic themes. The American Economic Review 76 (2), 393-398.

Sutton, J., 1991. "Sunk Costs and Market Structure: Price Competition, Advertising, and the Evolution of Concentration". MIT Press, Cambridge MA.

Sutton, J., 1998. "Technology and Market Structure. Theory and History". MIT Press, Cambridge MA.

Teece, D. J., 2018. Profiting from innovation in the digital economy: Enabling technologies, standards, and licensing models in the wireless world. Research Policy 47 (8), $1367-1387$.

van Gompel, S., 2019. Patent abolition: A real-life historical case study. American University International Law Review 34, 877-922.

Ziedonis, R. H., 2008. On the apparent failure of patents: A response to bessen and meurer. Academy of Management Perspectives 22 (4), 21-29. 


\section{Appendix: Tables and Graphs}

Table A1: Countries included in the analysis

\begin{tabular}{lccc}
\hline \hline & & & \\
Austria & France & Lithuania & Slovenia \\
Belgium & Germany & Luxembourg & South Korea \\
Brazil & Greece & Malta & Spain \\
Bulgaria & Hungary & Netherlands & Sweden \\
Canada & India & Norway & Switzerland \\
China & Ireland & Poland & Taiwan \\
Croatia & Israel & Portugal & Turkey \\
Czech Republic & Italy & Romania & United Kingdom \\
Denmark & Japan & Russia & United States \\
Finland & Latvia & Slovakia & \\
\hline \hline
\end{tabular}

Table A2: The ICT perimeter based on NACE rev. 2 industries

\begin{tabular}{lcc}
\hline \hline & & \\
NACE Rev. 2 & Description & \\
\hline & & \\
26.1 & Manufacture of electronic components and boards & \multirow{2}{*}{ Manufacture of computers and peripheral equipment } \\
26.2 & Manufacture of communication equipment & \\
26.4 & Manufacture of consumer electronics & \\
\hline 58.2 & Software publishing & \\
61 & Telecommunications & \\
62 & Computer programming, consultancy and related activities & ICT services \\
63.1 & Data processing, hosting and related activities; web portals & \\
95.1 & Repair of computers and communication equipment & \\
& & \\
\hline \hline
\end{tabular}


Table A3: Firm-level outcomes and patenting activity in the corporate perimeter. Correlations.

\begin{tabular}{lccc}
\hline Variable & Coeff. & s. e. & N. obs. \\
\hline \hline Market share & $.040^{* * *}$ & $(.005)$ & 931,613 \\
Labor productivity & $.040^{* * *}$ & $(.005)$ & 931,613 \\
Firm size & $.079^{* * *}$ & $(.007)$ & 931,613 \\
Capital intensity & $.070^{* * *}$ & $(.006)$ & 931,613 \\
ROCE & $-.003^{* *}$ & $(.001)$ & 884,051
\end{tabular}

Note: Each coefficient is the result of a least-square regression of the (log) firm-level outcome (by row) vis á vis the sum of patents granted each year in the company and in their subsidiaries standardized with the inverse of an inverse hyperbolic sine transformation $\left(\ln \left(x+\sqrt{x^{2}+1}\right)\right)$ to approximate the natural logarithm while retaining zeros, as suggested by (Bellemare and Wichman, 2020). Firm-level controls, firm-level fixed effects, and country-year fixed effects are included. Firm-level clustered standard errors are reported.

Table A4: Treatment group: baseline and robustness checks

\begin{tabular}{ccc}
\hline \hline Year & $\begin{array}{c}(1) \\
\text { Treated } \\
\text { companies } \\
\text { (baseline) }\end{array}$ & $\begin{array}{c}(2) \\
\text { Treated } \\
\text { companies } \\
\text { (robustness) }\end{array}$ \\
\hline & & \\
2010 & 64 & 65 \\
2011 & 70 & 70 \\
2012 & 52 & 56 \\
2013 & 44 & 46 \\
2014 & 57 & 66 \\
2015 & 49 & 52 \\
2016 & 49 & 54 \\
2017 & 45 & 47 \\
\hline & & \\
Total & 432 & 454 \\
\hline \hline
\end{tabular}

Note: Column (1) counts companies that have been granted first patents in 2009-2017, i.e., belonging to the treatment group. Column (2) counts companies that have been granted their first patents either at the headquarters or subsidiary level in 2009-2017. 
Figure A1: Event study on market shares. The case of smaller firms

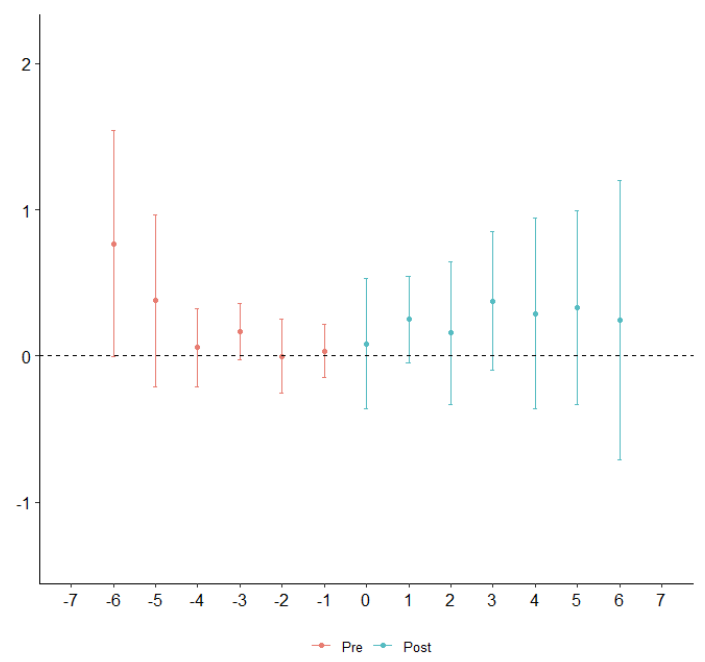

Note: Event study on market shares after patent grants following the approach by Callaway and Sant'Anna (2021). Smaller firms are the ones above the median at the beginning of the period. Parameters are estimated under parallel trend assumptions conditional on the number of employees, capital intensity, age (in logs), 2-digit sector and regional dummies. Blue lines denote point estimates and simultaneous $99 \%$ confidence bands for the effect of the treatment.

Figure A2: Event study on productivity. The case of smaller firms

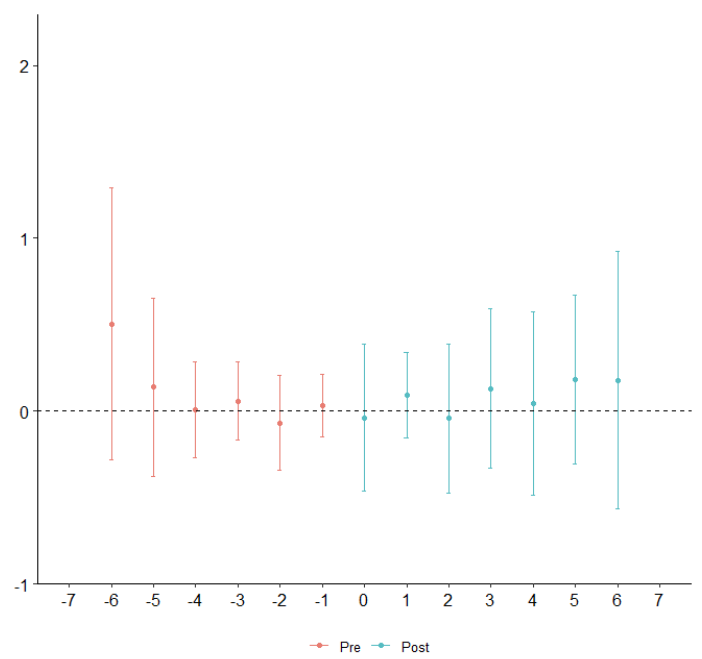

Note: Event study on labor productivity measured as value added per employee after patent grants following the approach by Callaway and Sant'Anna (2021). Smaller firms are the ones above the median at the beginning of the period. Parameters are estimated under parallel trend assumptions conditional on the number of employees, capital intensity, age (in logs), 2-digit sector and regional dummies. Blue lines denote point estimates and simultaneous $99 \%$ confidence bands for the effect of the treatment. 
Figure A3: Event study on firm size. The case of smaller firms

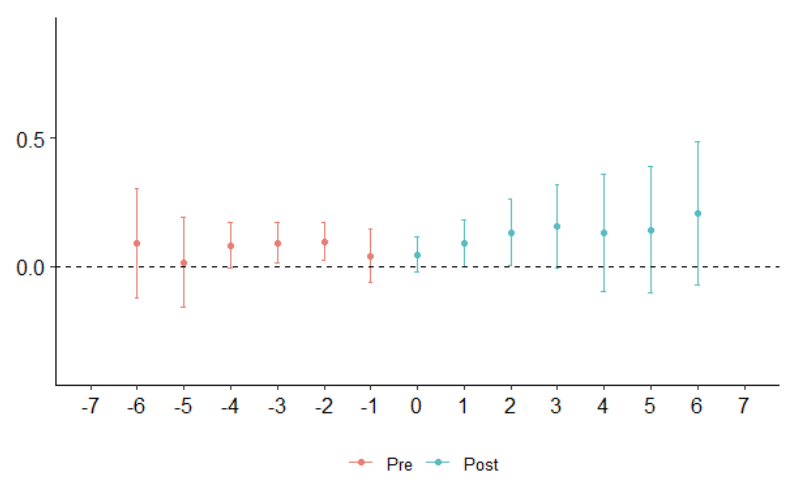

Note: Event study on firm size measured as log of revenues after patent grants following the approach by Callaway and Sant'Anna (2021). Smaller firms are the ones above the median at the beginning of the period. Parameters are estimated under parallel trend assumptions conditional on the number of employees, capital intensity, age (in logs), 2-digit sector and regional dummies. Blue lines denote point estimates and simultaneous $99 \%$ confidence bands for the effect of the treatment.

Figure A4: Event study on capital intensity. The case of smaller firms

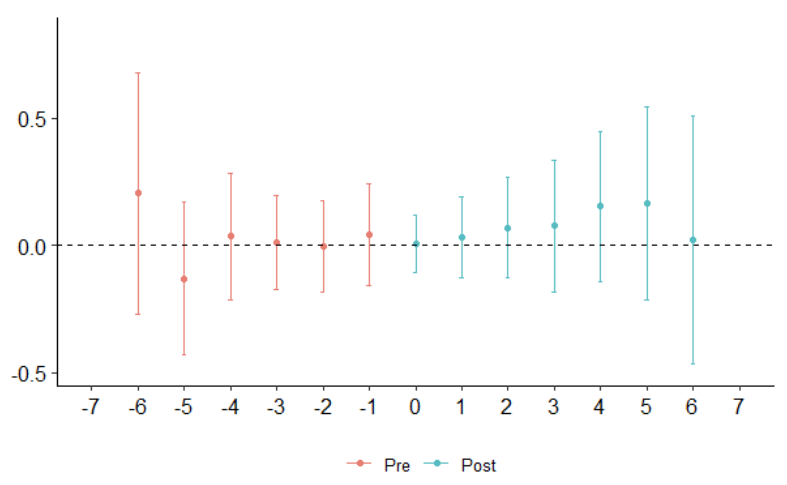

Note: Event study on market shares after patent grants following the approach by Callaway and Sant'Anna (2021). Smaller firms are the ones above the median at the beginning of the period. Parameters are estimated under parallel trend assumptions conditional on the number of employees, capital intensity, age (in logs), 2-digit sector and regional dummies. Blue lines denote point estimates and simultaneous $99 \%$ confidence bands for the effect of the treatment. 
Figure A5: Event study on profitability. The case of smaller firms

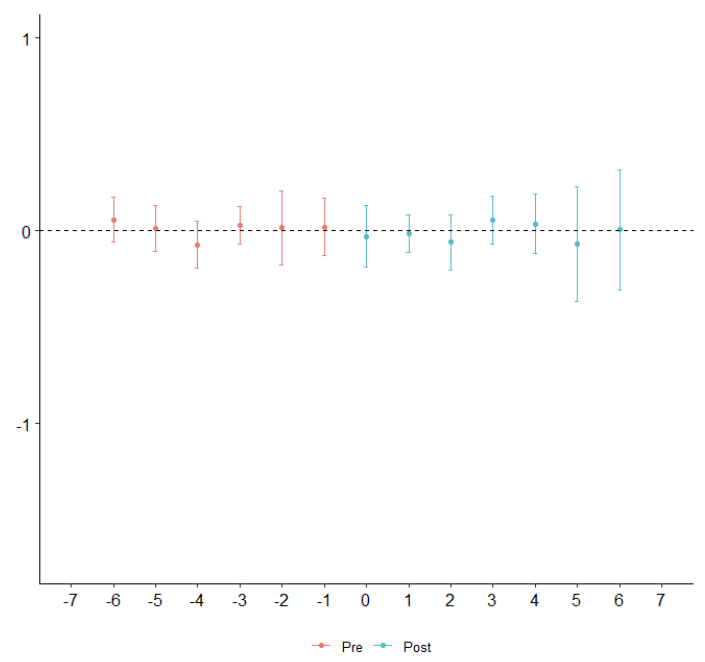

Note: Event study on market shares after patent grants following the approach by Callaway and Sant'Anna (2021). Smaller firms are the ones above the median at the beginning of the period. Parameters are estimated under parallel trend assumptions conditional on the number of employees, capital intensity, age (in logs), 2-digit sector and regional dummies. Blue lines denote point estimates and simultaneous $99 \%$ confidence bands for the effect of the treatment. 
Table A5: Profit margins and protection of intellectual property rights: an IV approach

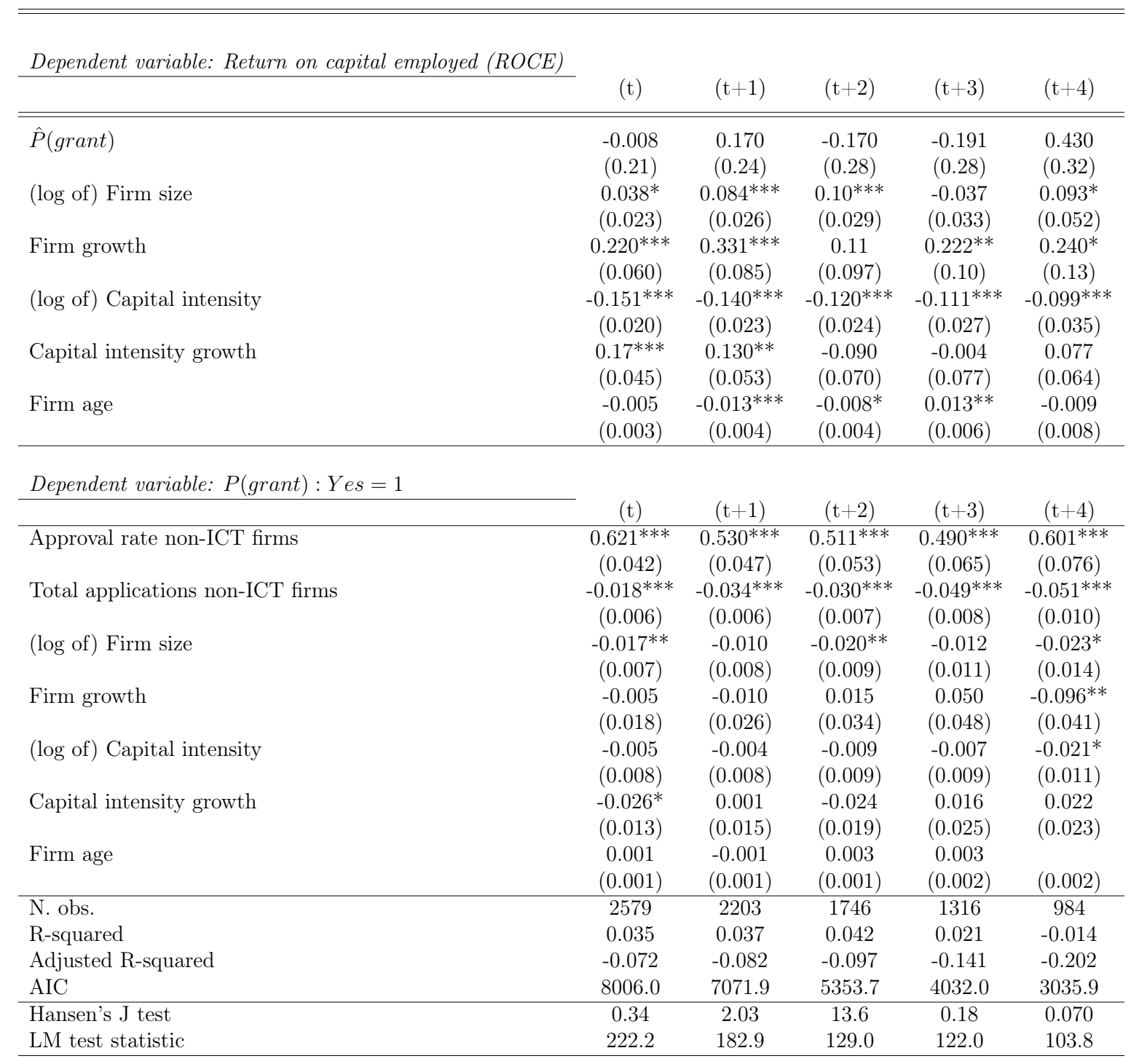

Note: The table illustrates the impact of a patent grant on firm-level market shares (outcome equation) after an IV approach that controls (first stage) the endogenous role of innovation contents after exogenous variation on assignees in non-ICT industries that innovate in the same technologies and the same year of ICT firms. At the bottom of the table, we record tests on the weakness of instruments. Estimates are obtained after an optimal GMM estimation with robust standard errors in parentheses. ${ }^{*} \mathrm{p}<0.1 ;{ }^{* *} \mathrm{p}<0.05 ;{ }^{* * *} \mathrm{p}<0.01$. 
Table A6: Market shares and protection of property rights: an IV approach, considering the corporate perimeter

\begin{tabular}{|c|c|c|c|c|c|}
\hline \multirow[t]{2}{*}{ Dependent variable: (log of) Market share } & \multirow[b]{2}{*}{$(\mathrm{t})$} & \multirow[b]{2}{*}{$(\mathrm{t}+1)$} & \multirow[b]{2}{*}{$(\mathrm{t}+2)$} & \multirow[b]{2}{*}{$(\mathrm{t}+3)$} & \multirow[b]{2}{*}{$(\mathrm{t}+4)$} \\
\hline & & & & & \\
\hline \multirow[t]{2}{*}{$\hat{P}($ grant $)$} & $0.21^{* *}$ & 0.24 & 0.26 & 0.23 & 0.25 \\
\hline & $(0.095)$ & $(0.13)$ & $(0.14)$ & $(0.15)$ & $(0.21)$ \\
\hline \multirow[t]{2}{*}{ (log of) Firm size } & $1.08^{* * *}$ & $1.09^{* * *}$ & $1.10^{* * *}$ & $1.09 * * *$ & $1.07^{* * *}$ \\
\hline & $(0.0066)$ & $(0.0079)$ & $(0.0092)$ & $(0.011)$ & $(0.015)$ \\
\hline \multirow[t]{2}{*}{ Firm size growth } & $-0.24^{* * *}$ & $-0.21^{* * *}$ & $-0.23^{* * *}$ & $-0.14^{* *}$ & -0.10 \\
\hline & $(0.040)$ & $(0.046)$ & $(0.046)$ & $(0.063)$ & $(0.072)$ \\
\hline \multirow[t]{2}{*}{ (log of) Capital intensity } & $0.22^{* * *}$ & $0.23^{* * *}$ & $0.22^{* * *}$ & $0.18^{* * *}$ & $0.15^{* * *}$ \\
\hline & $(0.0095)$ & $(0.011)$ & $(0.012)$ & $(0.015)$ & $(0.019)$ \\
\hline \multirow[t]{2}{*}{ Capital intensity growth } & $-0.066^{*}$ & $-0.100^{* * *}$ & 0.018 & $0.12^{* * *}$ & $0.11^{* *}$ \\
\hline & $(0.035)$ & $(0.025)$ & $(0.037)$ & $(0.041)$ & $(0.046)$ \\
\hline \multirow[t]{2}{*}{ (log of) Firm age } & $-0.0017^{* * *}$ & $-0.0019^{* * *}$ & $-0.0030^{* * *}$ & $-0.0029 * * *$ & $-0.0028^{* * *}$ \\
\hline & $(0.00045)$ & $(0.00047)$ & $(0.00052)$ & $(0.00063)$ & $(0.00079)$ \\
\hline \multirow[t]{2}{*}{ Dependent variable: $P($ grant $): Y e s=1$} & & & & & \\
\hline & $(\mathrm{t})$ & $(\mathrm{t}+1)$ & $(\mathrm{t}+2)$ & $(\mathrm{t}+3)$ & $(\mathrm{t}+4)$ \\
\hline \multirow[t]{2}{*}{ Approval rate non-ICT } & $0.60^{* * *}$ & $0.64^{* * *}$ & $0.61^{* * *}$ & $0.60^{* * *}$ & $0.54^{* * *}$ \\
\hline & $(0.021)$ & $(0.027)$ & $(0.031)$ & $(0.036)$ & $(0.044)$ \\
\hline \multirow[t]{2}{*}{ Total applications non-ICT } & $-0.027 * * *$ & $-0.031^{* * *}$ & $-0.039^{* * *}$ & $-0.042^{* * *}$ & $-0.039^{* * *}$ \\
\hline & $(0.0032)$ & $(0.0036)$ & $(0.0039)$ & $(0.0046)$ & $(0.0060)$ \\
\hline \multirow[t]{2}{*}{ (log of) Firm size } & $-0.013^{* * *}$ & $-0.010^{* * *}$ & $-0.0080^{* *}$ & -0.0022 & -0.00031 \\
\hline & $(0.0027)$ & $(0.0029)$ & $(0.0032)$ & $(0.0038)$ & $(0.0049)$ \\
\hline \multirow[t]{2}{*}{ Firm size growth } & $0.041^{* * *}$ & $0.059^{* * *}$ & $0.032^{*}$ & 0.016 & $-0.073^{* * *}$ \\
\hline & $(0.010)$ & $(0.016)$ & $(0.017)$ & $(0.025)$ & $(0.024)$ \\
\hline \multirow[t]{2}{*}{ (log of) Capital intensity } & -0.0046 & $-0.0069^{* *}$ & -0.0029 & $-0.0078^{* *}$ & $-0.015^{* * *}$ \\
\hline & $(0.0030)$ & $(0.0033)$ & $(0.0034)$ & $(0.0038)$ & $(0.0047)$ \\
\hline \multirow[t]{2}{*}{ Capital intensity growth } & 0.0046 & $0.023^{* *}$ & -0.014 & 0.0100 & -0.0041 \\
\hline & $(0.0076)$ & $(0.010)$ & $(0.013)$ & $(0.017)$ & $(0.016)$ \\
\hline \multirow[t]{2}{*}{ (log of) Firm age } & 0.00020 & 0.00023 & $0.00037^{*}$ & 0.00033 & 0.00011 \\
\hline & $(0.00021)$ & $(0.00020)$ & $(0.00021)$ & $(0.00022)$ & $(0.00026)$ \\
\hline No. obs, & 8058 & 6000 & 4445 & 3258 & 2330 \\
\hline R-squared & 0.799 & 0.838 & 0.839 & 0.747 & 0.713 \\
\hline Adjusted R-squared & 0.745 & 0.784 & 0.779 & 0.624 & 0.567 \\
\hline $\mathrm{AIC}$ & 752.9 & 521.9 & 393.3 & 218.4 & 189.3 \\
\hline Hansen J test & 11.5 & 0.19 & 0.011 & 9.31 & 5.92 \\
\hline LM test statistic & 610.8 & 428.3 & 324.5 & 237.9 & 185.1 \\
\hline
\end{tabular}

Note: The table illustrates the impact of a patent grant on firm-level market shares (outcome equation) after an IV approach that controls (first stage) the endogenous role of innovation contents after exogenous variation on assignees in non-ICT industries that innovate in the same technologies and the same year of ICT firms. At the bottom of the table, we record tests on the weakness of instruments. Estimates are obtained after an optimal GMM estimation with robust standard errors in parentheses. ${ }^{*} \mathrm{p}<0.1 ;{ }^{* *} \mathrm{p}<0.05 ;{ }^{* * *} \mathrm{p}<0.01$. 
Table A7: Firm size and protection of intellectual property rights: an IV approach, considering the corporate perimeter

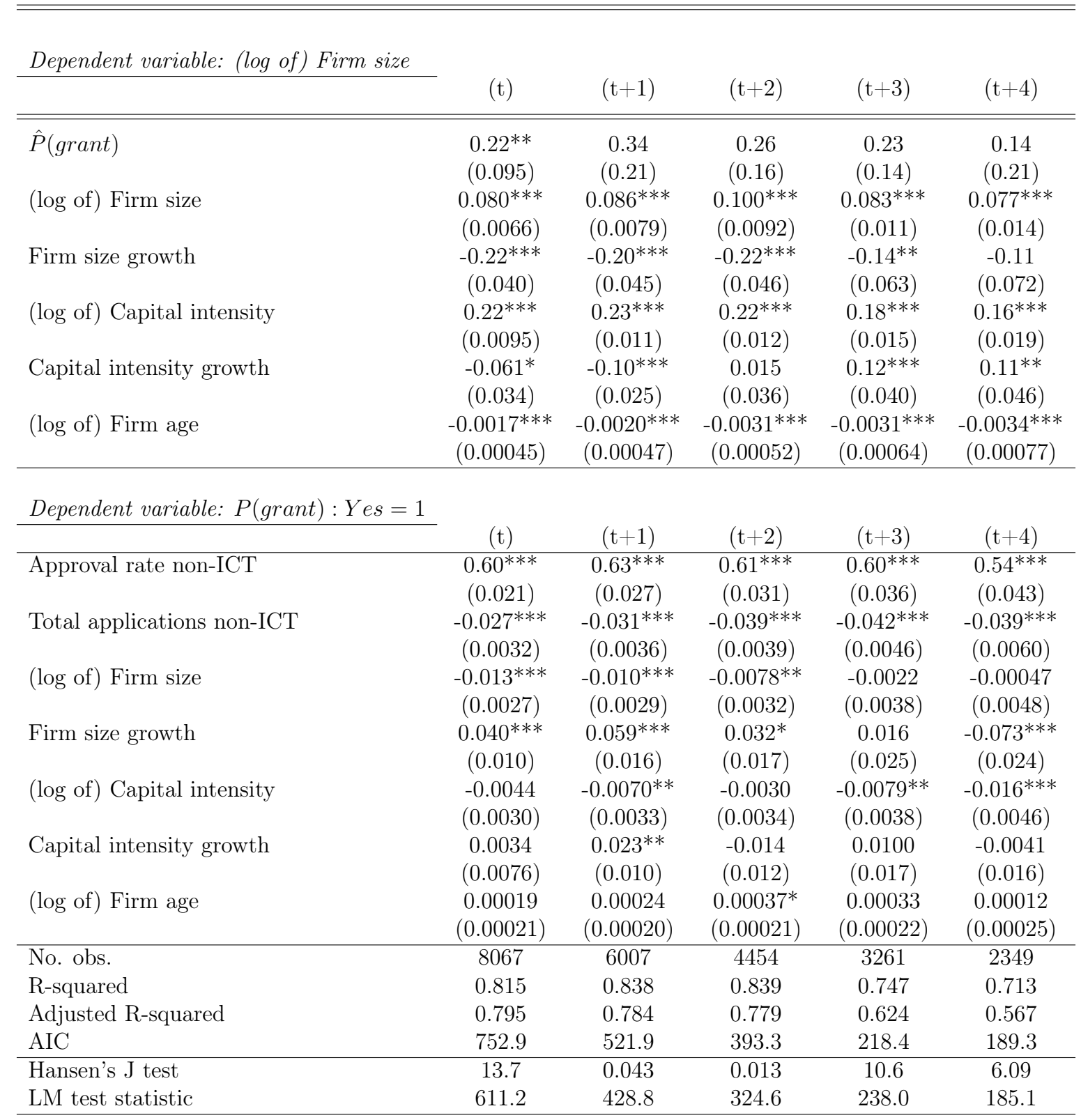

Note: The table illustrates the impact of a patent grant on firm-level market shares (outcome equation) after an IV approach that controls (first stage) the endogenous role of innovation contents after exogenous variation on assignees in non-ICT industries that innovate in the same technologies and the same year of ICT firms. At the bottom of the table, we record tests on the weakness of instruments. Estimates are obtained after an optimal GMM estimation with robust standard errors in parentheses. ${ }^{*} \mathrm{p}<0.1 ;{ }^{* *} \mathrm{p}<0.05 ;{ }^{* * *} \mathrm{p}<0.01$. 
Table A8: Market shares and protection of intellectual property rights; an IV approach, only incumbent firms

\begin{tabular}{|c|c|c|c|c|c|}
\hline Dependent variable: (log of) Market share & $(\mathrm{t})$ & $(t+1)$ & $(\mathrm{t}+2)$ & $(\mathrm{t}+3)$ & $(\mathrm{t}+4)$ \\
\hline$\hat{P}($ grant $)$ & $\begin{array}{c}0.17^{* * *} \\
(0.06)\end{array}$ & $\begin{array}{l}-0.19 \\
(0.20)\end{array}$ & $\begin{array}{c}0.27 \\
(0.24)\end{array}$ & $\begin{array}{l}0.091 \\
(0.22)\end{array}$ & $\begin{array}{c}0.17 \\
(0.21)\end{array}$ \\
\hline (log of) Firm size & $\begin{array}{c}1.03^{* * *} \\
(0.031)\end{array}$ & $\begin{array}{c}1.04^{* * *} \\
(0.039)\end{array}$ & $\begin{array}{c}1.06^{* * *} \\
(0.041)\end{array}$ & $\begin{array}{l}1.05^{* * *} \\
(0.069)\end{array}$ & $\begin{array}{c}0.98^{* * *} \\
(0.076)\end{array}$ \\
\hline Firm growth & $\begin{array}{c}-0.40^{* * *} \\
(0.15)\end{array}$ & $\begin{array}{l}0.060 \\
(0.21)\end{array}$ & $\begin{array}{c}-0.68^{* * *} \\
(0.18)\end{array}$ & $\begin{array}{l}-0.21 \\
(0.16)\end{array}$ & $\begin{array}{l}0.041 \\
(0.27)\end{array}$ \\
\hline (log of) Capital intensity & $\begin{array}{c}0.12^{* * *} \\
(0.030)\end{array}$ & $\begin{array}{c}0.099^{* * *} * \\
(0.031)\end{array}$ & $\begin{array}{l}0.0024 \\
(0.036)\end{array}$ & $\begin{array}{l}-0.076 \\
(0.049)\end{array}$ & $\begin{array}{l}-0.073 \\
(0.060)\end{array}$ \\
\hline Capital intensity growth & $\begin{array}{c}-0.013 \\
(0.033)\end{array}$ & $\begin{array}{c}-0.064 \\
(0.048)\end{array}$ & $\begin{array}{c}0.095 \\
(0.063)\end{array}$ & $\begin{array}{r}-0.0099 \\
(0.068)\end{array}$ & $\begin{array}{c}0.0079 \\
(0.091)\end{array}$ \\
\hline Firm age & $\begin{array}{c}-0.0088^{*} \\
(0.0050)\end{array}$ & $\begin{array}{l}-0.0028 \\
(0.0049)\end{array}$ & $\begin{array}{l}-0.0040 \\
(0.0045)\end{array}$ & $\begin{array}{c}-0.014^{* * *} \\
(0.0051)\end{array}$ & $\begin{array}{c}-0.018^{* * *} \\
(0.0061)\end{array}$ \\
\hline
\end{tabular}

Dependent variable: $P($ grant $): Y e s=1$

\begin{tabular}{lccccc}
\hline & $(\mathrm{t})$ & $(\mathrm{t}+1)$ & $(\mathrm{t}+2)$ & $(\mathrm{t}+3)$ & $(\mathrm{t}+4)$ \\
\hline Approval rate non-ICT firms & $0.46^{* * *}$ & $0.40^{* * *}$ & $0.39^{* * *}$ & $0.44^{* * *}$ & $0.51^{* * *}$ \\
Total applications non-ICT firms & $(0.078)$ & $(0.10)$ & $(0.12)$ & $(0.15)$ & $(0.18)$ \\
& $-0.022^{* *}$ & $-0.030^{* * *}$ & $-0.037^{* * *}$ & -0.028 & $-0.038^{* *}$ \\
(log of) firm size & $(0.0093)$ & $(0.011)$ & $(0.014)$ & $(0.018)$ & $(0.019)$ \\
& -0.011 & -0.0086 & -0.021 & $-0.075^{*}$ & -0.061 \\
Firm growth & $(0.023)$ & $(0.026)$ & $(0.027)$ & $(0.044)$ & $(0.054)$ \\
& -0.041 & -0.038 & 0.011 & -0.11 & -0.14 \\
(log of) Capital intensity & $(0.069)$ & $(0.087)$ & $(0.084)$ & $(0.11)$ & $(0.26)$ \\
& -0.0071 & -0.014 & -0.021 & 0.0016 & 0.0015 \\
Capital intensity growth & $(0.021)$ & $(0.024)$ & $(0.025)$ & $(0.036)$ & $(0.038)$ \\
& -0.042 & -0.037 & 0.022 & $0.089^{*}$ & -0.093 \\
Firm age & $(0.030)$ & $(0.032)$ & $(0.049)$ & $(0.053)$ & $(0.061)$ \\
& -0.0011 & 0.00054 & 0.0012 & 0.0045 & -0.00086 \\
& $(0.0029)$ & $(0.0033)$ & $(0.0036)$ & $(0.0052)$ & $(0.0050)$ \\
\hline N. obs. & 681 & 521 & 372 & 252 & 199 \\
R-squared & 0.799 & 0.838 & 0.839 & 0.747 & 0.713 \\
Adjusted R-squared & 0.745 & 0.784 & 0.779 & 0.624 & 0.567 \\
AIC & 752.9 & 521.9 & 393.3 & 218.4 & 189.3 \\
\hline Hansen's J test & 2.13 & 0.86 & 2.01 & 0.36 & 0.36 \\
LM test statistic & 45.5 & 30.5 & 28.1 & 22.4 & 19.8 \\
\hline
\end{tabular}

Note: The table illustrates the impact of a patent grant on firm-level market shares (outcome equation) after an IV approach that controls (first stage) the endogenous role of innovation contents after exogenous variation on assignees in non-ICT industries that innovate in the same technologies and the same year of ICT firms. At the bottom of the table, we record tests on the weakness of instruments. Estimates are obtained after an optimal GMM estimation with robust standard errors in parentheses. ${ }^{*} \mathrm{p}<0.1 ;{ }^{* *} \mathrm{p}<0.05 ;{ }^{* * *} \mathrm{p}<0.01$. 
Table A9: Market shares and protection of intellectual property rights: an IV approach, considering firms in the US, Japan, and South Korea

\begin{tabular}{|c|c|c|c|c|c|}
\hline Dependent variable: (log of) Market share & $(\mathrm{t})$ & $(t+1)$ & $(t+2)$ & $(t+3)$ & $(t+4)$ \\
\hline$\hat{P}($ grant $)$ & $\begin{array}{c}0.60^{* * *} \\
(0.23)\end{array}$ & $\begin{array}{c}0.61^{* * *} \\
(0.23)\end{array}$ & $\begin{array}{c}0.57^{* * *} \\
(0.16)\end{array}$ & $\begin{array}{c}0.56 \\
(0.37)\end{array}$ & $\begin{array}{c}0.31 \\
(0.31)\end{array}$ \\
\hline (log of) Firm size & $\begin{array}{c}1.14^{* * *} \\
(0.027)\end{array}$ & $\begin{array}{l}1.17^{* * *} \\
(0.035)\end{array}$ & $\begin{array}{l}1.16^{* * *} \\
(0.042)\end{array}$ & $\begin{array}{l}1.12^{* * *} \\
(0.041)\end{array}$ & $\begin{array}{l}1.27^{* * *} \\
(0.042)\end{array}$ \\
\hline Firm growth & $\begin{array}{c}-0.22^{* * *} \\
(0.053)\end{array}$ & $\begin{array}{c}-0.28^{* *} \\
(0.11)\end{array}$ & $\begin{array}{c}-0.25^{* *} \\
(0.10)\end{array}$ & $\begin{array}{l}0.024 \\
(0.11)\end{array}$ & $\begin{array}{c}0.16 \\
(0.14)\end{array}$ \\
\hline (log of) Capital intensity & $\begin{array}{c}0.20^{* * *} \\
(0.021)\end{array}$ & $\begin{array}{c}0.25^{* * *} \\
(0.018)\end{array}$ & $\begin{array}{c}0.28^{* * *} \\
(0.021)\end{array}$ & $\begin{array}{c}0.27^{* * *} \\
(0.025)\end{array}$ & $\begin{array}{c}0.28^{* * *} \\
(0.023)\end{array}$ \\
\hline Capital intensity growth & $\begin{array}{c}0.00063 \\
(0.043)\end{array}$ & $\begin{array}{l}-0.040 \\
(0.061)\end{array}$ & $\begin{array}{l}-0.023 \\
(0.079)\end{array}$ & $\begin{array}{c}0.17^{*} \\
(0.095)\end{array}$ & $\begin{array}{c}0.26^{* *} \\
(0.10)\end{array}$ \\
\hline Firm age & $\begin{array}{l}-0.0016 \\
(0.0035)\end{array}$ & $\begin{array}{l}-0.0047 \\
(0.0045)\end{array}$ & $\begin{array}{r}-0.00031 \\
(0.0056)\end{array}$ & $\begin{array}{l}-0.0062 \\
(0.0060)\end{array}$ & $\begin{array}{c}-0.024^{* * *} \\
(0.0056)\end{array}$ \\
\hline
\end{tabular}

Dependent variable: $P($ grant $): Y e s=1$

\begin{tabular}{lccccc}
\cline { 1 - 4 } Approval rate non-ICT firms & $(\mathrm{t})$ & $(\mathrm{t}+1)$ & $(\mathrm{t}+2)$ & $(\mathrm{t}+3)$ & $(\mathrm{t}+4)$ \\
& $0.81^{* * *}$ & $0.77^{* * *}$ & $0.73^{* * *}$ & $0.78^{* * *}$ & $0.91^{* * *}$ \\
Total applications non-ICT firms & $(0.069)$ & $(0.071)$ & $(0.079)$ & $(0.086)$ & $(0.11)$ \\
& $-0.035^{*}$ & $-0.059^{* * *}$ & $-0.055^{* *}$ & $-0.12^{* * *}$ & $-0.28^{* * *}$ \\
(log of) Firm size & $(0.017)$ & $(0.019)$ & $(0.025)$ & $(0.046)$ & $(0.054)$ \\
& -0.017 & -0.017 & $-0.037^{* * *}$ & -0.0075 & -0.017 \\
Firm growth & $(0.011)$ & $(0.013)$ & $(0.014)$ & $(0.016)$ & $(0.019)$ \\
& 0.030 & 0.035 & $0.11^{* *}$ & 0.088 & -0.084 \\
(log of) Capital intensity & $(0.028)$ & $(0.034)$ & $(0.046)$ & $(0.062)$ & $(0.078)$ \\
& -0.0094 & -0.0075 & -0.014 & -0.015 & -0.021 \\
Capital intensity growth & $(0.012)$ & $(0.012)$ & $(0.012)$ & $(0.013)$ & $(0.013)$ \\
& -0.0059 & 0.035 & 0.0050 & 0.018 & 0.023 \\
Firm age & $(0.022)$ & $(0.027)$ & $(0.036)$ & $(0.048)$ & $(0.051)$ \\
& 0.0011 & -0.00012 & 0.0026 & 0.00062 & 0.0019 \\
N. obs. & $(0.0018)$ & $(0.0020)$ & $(0.0022)$ & $(0.0027)$ & $(0.0033)$ \\
R-squared & 1496 & 1295 & 1046 & 859 & 626 \\
Adjusted R-squared & 0.792 & 0.763 & 0.746 & 0.681 & 0.767 \\
AIC & 0.768 & 0.733 & 0.710 & 0.633 & 0.727 \\
Hansen's J test & 3534.8 & 3203.3 & 2602.4 & 2173.6 & 1393.7 \\
LM test statistic & 8.82 & 4.06 & 0.45 & 2.56 & 0.73 \\
\hline
\end{tabular}

Note: The table illustrates the impact of a patent grant on firm-level market shares (outcome equation) after an IV approach that controls (first stage) the endogenous role of innovation contents after exogenous variation on assignees in non-ICT industries that innovate in the same technologies and the same year of ICT firms. At the bottom of the table, we record tests on the weakness of instruments. Estimates are obtained after an optimal GMM estimation with robust standard errors in parentheses. ${ }^{*} \mathrm{p}<0.1 ;{ }^{* *} \mathrm{p}<0.05 ;{ }^{* * *} \mathrm{p}<0.01$. 
Table A10: Market shares and protection of intellectual property rights: an IV approach, considering firms in the European Union

Dependent variable: (log of) Market share

\begin{tabular}{|c|c|c|c|c|c|}
\hline & $(\mathrm{t})$ & $(\mathrm{t}+1)$ & $(\mathrm{t}+2)$ & $(\mathrm{t}+3)$ & $(\mathrm{t}+4)$ \\
\hline$\hat{P}($ grant $)$ & $\begin{array}{c}0.36^{* *} \\
(0.14)\end{array}$ & $\begin{array}{c}0.21 \\
(0.14)\end{array}$ & $\begin{array}{c}0.13 \\
(0.18)\end{array}$ & $\begin{array}{l}-0.31 \\
(0.21)\end{array}$ & $\begin{array}{c}0.31 \\
(0.23)\end{array}$ \\
\hline (log of) Firm size & $\begin{array}{l}1.01^{* * *} \\
(0.023)\end{array}$ & $\begin{array}{l}1.06^{* * *} \\
(0.021)\end{array}$ & $\begin{array}{l}1.11^{* * *} \\
(0.025)\end{array}$ & $\begin{array}{l}1.11^{* * *} \\
(0.036)\end{array}$ & $\begin{array}{l}1.15^{* * *} \\
(0.039)\end{array}$ \\
\hline Firm growth & $\begin{array}{c}-0.42^{* * * *} \\
(0.072)\end{array}$ & $\begin{array}{c}-0.49^{* * *} \\
(0.093)\end{array}$ & $\begin{array}{c}-0.47^{* * *} \\
(0.11)\end{array}$ & $\begin{array}{c}-0.59^{* * * *} \\
(0.14)\end{array}$ & $\begin{array}{c}-0.29^{* *} \\
(0.12)\end{array}$ \\
\hline (log of) Capital intensity & $\begin{array}{c}0.12^{* * *} \\
(0.023)\end{array}$ & $\begin{array}{c}0.030 \\
(0.019)\end{array}$ & $\begin{array}{c}0.035 \\
(0.022)\end{array}$ & $\begin{array}{c}0.047^{*} \\
(0.026)\end{array}$ & $\begin{array}{c}0.084^{* *} \\
(0.035)\end{array}$ \\
\hline Capital intensity growth & $\begin{array}{l}-0.036 \\
(0.036)\end{array}$ & $\begin{array}{c}-0.18^{* * *} \\
(0.046)\end{array}$ & $\begin{array}{l}-0.042 \\
(0.070)\end{array}$ & $\begin{array}{l}-0.040 \\
(0.042)\end{array}$ & $\begin{array}{c}-0.15^{* * *} \\
(0.036)\end{array}$ \\
\hline Firm age & $\begin{array}{c}0.026^{* * *} \\
(0.0030)\end{array}$ & $\begin{array}{c}0.019 * * * \\
(0.0031)\end{array}$ & $\begin{array}{c}0.016^{* * *} \\
(0.0038)\end{array}$ & $\begin{array}{c}0.011^{*} \\
(0.0056)\end{array}$ & $\begin{array}{c}0.00050 \\
(0.0056)\end{array}$ \\
\hline
\end{tabular}

Dependent variable: $P($ grant $):$ Yes $=1$

\begin{tabular}{lccccc}
\cline { 1 - 4 } Approval rate non-ICT & $(\mathrm{t})$ & $(\mathrm{t}+1)$ & $(\mathrm{t}+2)$ & $(\mathrm{t}+3)$ & $(\mathrm{t}+4)$ \\
Total applications non-ICT & $0.56^{* * *}$ & $0.51^{* * *}$ & $0.32^{* * *}$ & $0.38^{* * *}$ & $0.44^{* * *}$ \\
& $(0.041)$ & $(0.049)$ & $(0.053)$ & $(0.065)$ & $(0.080)$ \\
(log of) Firm size & $-0.031^{* * *}$ & $-0.037^{* * *}$ & $-0.051^{* * *}$ & $-0.047^{* * *}$ & $-0.039^{* * *}$ \\
& $(0.0051)$ & $(0.0058)$ & $(0.0059)$ & $(0.0069)$ & $(0.0096)$ \\
Firm growth & -0.0026 & -0.0085 & -0.0034 & -0.013 & 0.00052 \\
& $(0.0086)$ & $(0.0089)$ & $(0.0097)$ & $(0.012)$ & $(0.014)$ \\
(log of) Capital intensity & -0.022 & $-0.069^{* *}$ & 0.026 & -0.050 & -0.029 \\
& $(0.019)$ & $(0.027)$ & $(0.040)$ & $(0.048)$ & $(0.052)$ \\
Capital intensity growth & -0.012 & -0.013 & 0.000012 & 0.0016 & -0.0048 \\
& $(0.0073)$ & $(0.0082)$ & $(0.0089)$ & $(0.010)$ & $(0.016)$ \\
Firm age & -0.021 & 0.0031 & -0.021 & -0.020 & 0.013 \\
& $(0.013)$ & $(0.015)$ & $(0.020)$ & $(0.022)$ & $(0.023)$ \\
N. obs. & 0.0019 & $0.0037^{* *}$ & 0.0022 & $0.0074^{* * *}$ & $0.0094^{* * *}$ \\
R-squared & $(0.0014)$ & $(0.0016)$ & $(0.0018)$ & $(0.0021)$ & $(0.0030)$ \\
Adjusted R-squared & 2053 & 1611 & 1179 & 804 & 543 \\
AIC & 0.712 & 0.793 & 0.802 & 0.786 & 0.812 \\
Hansen's J test & 0.675 & 0.761 & 0.766 & 0.737 & 0.761 \\
LM test statistic & 5354.8 & 3709.3 & 2665.6 & 1725.3 & 1053.7 \\
\hline
\end{tabular}

Note: The table illustrates the impact of a patent grant on firm-level market shares (outcome equation) after an IV approach that controls (first stage) the endogenous role of innovation contents after exogenous variation on assignees in non-ICT industries that innovate in the same technologies and the same year of ICT firms. At the bottom of the table, we record tests on the weakness of instruments. Estimates are obtained after an optimal GMM estimation with robust standard errors in parentheses. ${ }^{*} \mathrm{p}<0.1 ;{ }^{* *} \mathrm{p}<0.05 ;{ }^{* *} \mathrm{p}<0.01$. 